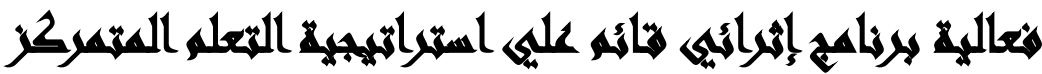

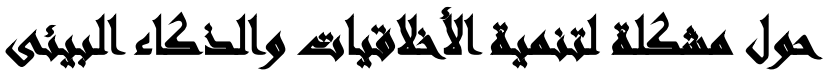

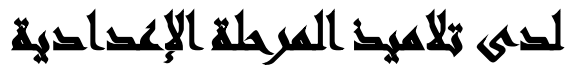

[9]

صفية أحمد محمد علي(')- عبد المسيح سمعان عبد المسيح(') (1)

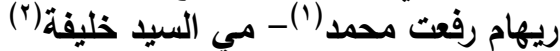

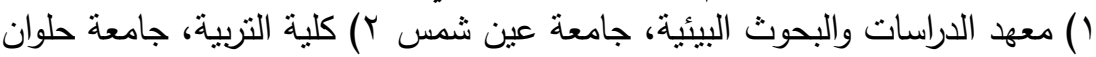

\section{المستيطلى}

هدف البحث إلى تتمية الأخلاقيات والذكاء البيئى من خلال إعداد برنامج قائم على إعلى

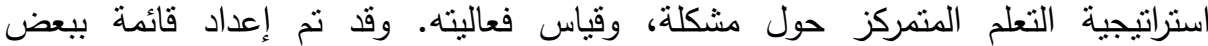

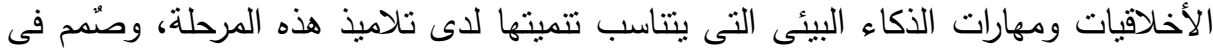

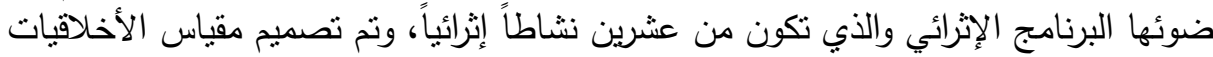

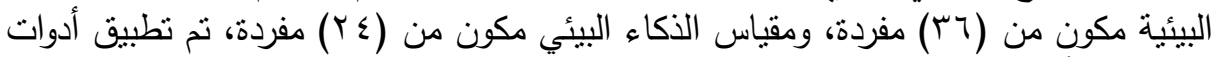

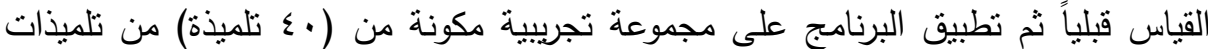
الصف الثاني الإعدادي، ثم تطبيق أدوات القياس بعدياً.

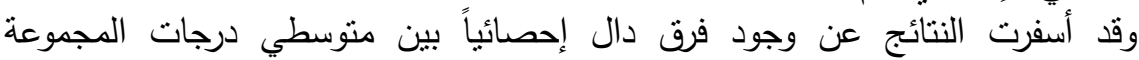

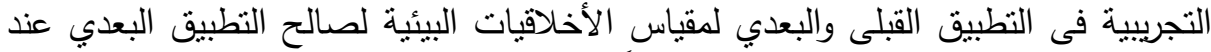

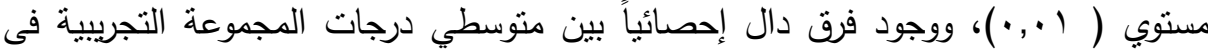

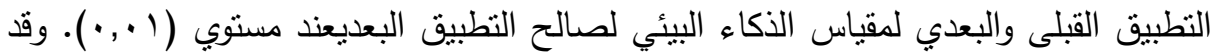

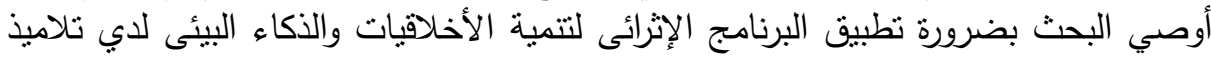

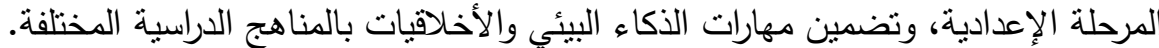

\section{xamatl}

البشر لا يحلون المشاكل، التي تصيب البيئة التي يعيشون فيها بقدر ما أن نشاطهم

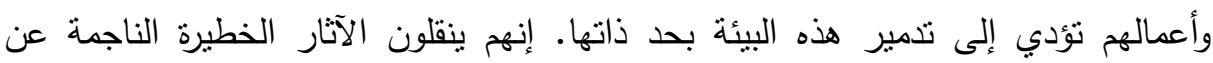

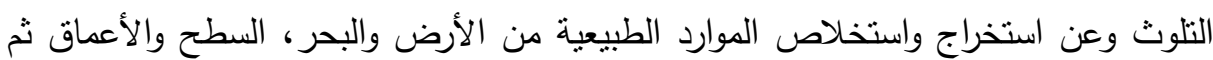

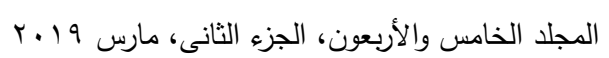


يتركوا ما يتخلف عن ذللك، رغم آثاره السلبية المدمرة في بعض الأحيان كي تصيب كل ما

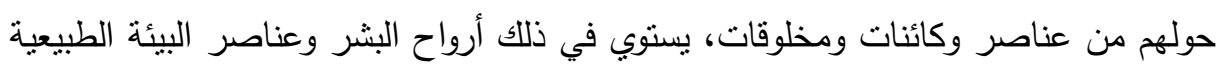
التي لا غنى عنها كي يعيش هؤلاء البشر .

كما أن عولمة النمط الاستهلاكي المفرط ستؤدي في حال إمكانية نطبيقها إلى إلى كارثة بيئية لا تحتمل، ففي ظل اقتصاد استهلاكي ينظر إلى الطبيعة على أنها مجرد مادة أولية

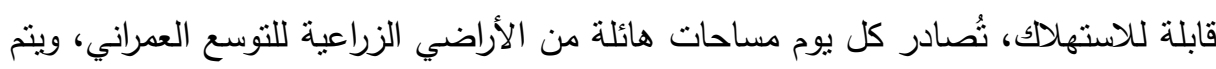

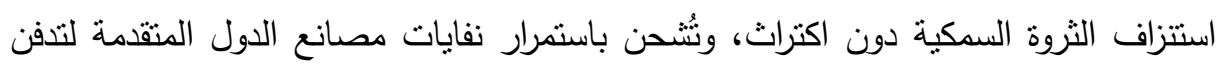
في أراضي العالم النامي. فمصير الإنسان، مرتبط بالنوازنات البيولوجية وبالسلاسل الغذائية التي تحتويها النظم البيئية، وأن أي إخلال بهذه التوازنات والسلاسل ينعكس مباشرة علي حياة الإنسان ولهذا فإن الفان

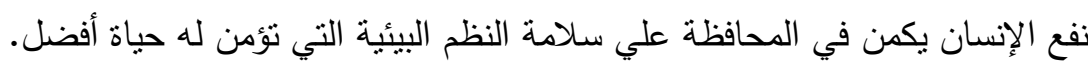

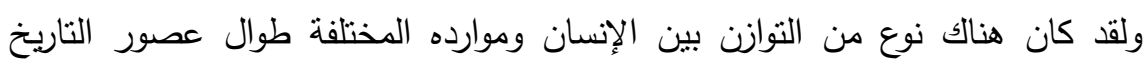

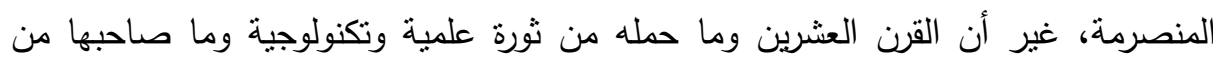

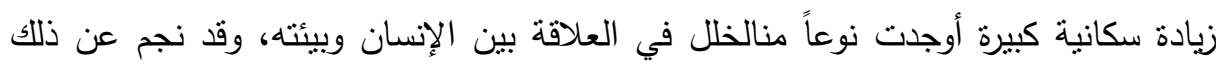
أمران خطيران هما اسنتزاف الموارد وتلوثها ـ ففي النصف الأخير من القرن العشرين تأثرت التران المصادر الطبيعية الموجودة في البحار وعلى الأرض وفي الجو وتلوثت مسببة أخطاراً لا

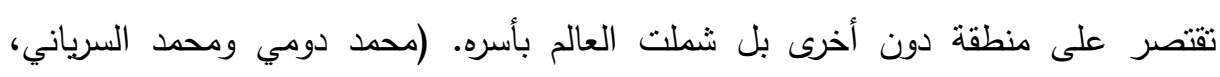
(109, r...

ويتعرض العالم المعاصر لموجة من الهزات الاخلاقية المتتابعة، وتحديات اخلاقية وازمات وكوارث بيئية، والتي تتمثل في مظاهر مختلفة من الممارسات وانماط السلوك الفردي لهي

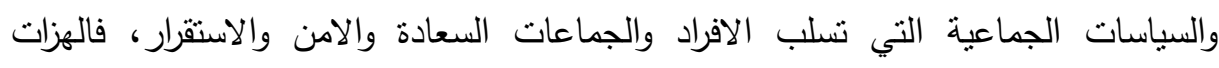

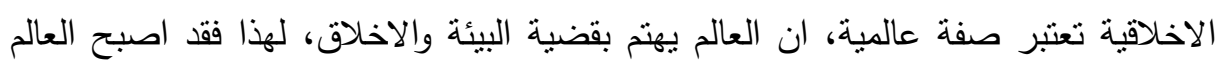
متلكفاً للبحث عن ضوابط وقوانين واحكام دينية وقيمية واخلاقية تحكم استخدام الثقنيات

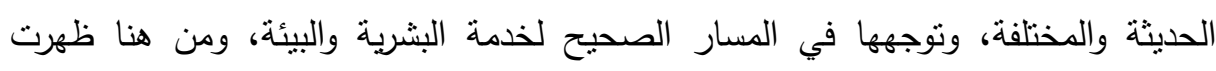
اخلاق العلم بصفة عامة والاخلاق البيئية بصفة خاصة كاتجاه جديد في السنوات القلائل 
الماضية، ليفرض نفسه كمتغير جديد على المناهج في مختلف المجالات وكافة التخصصات بصفة عامة.

إن الإجراءات التي تتخذ لحماية البيئة والمحافظة عليها ومواجهة مشكلاتها، ينبغيأن تبدأ بالإنسان باعتباره المسؤول عن ظهور هذه المشكلات. والأساس في هذالثأنأن يرجع الى تربية الإنسان نفسه تربية بيئية يفهم من خلالها أسس التفاعل الصحيح مع بيئته، ويقتتع بأهمية

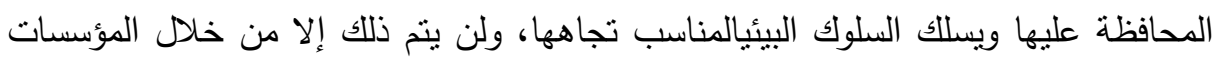
التربوية المختلفة التيتهنم بتتمية ميوله ومعارفه واتجاهاته نحو بيئته، ويرجع علماء التربية

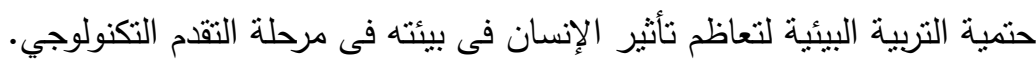

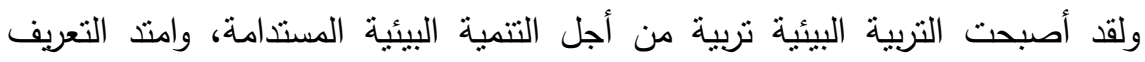
ليشمل البيئة الطبيعية والبيئة الاجتماعية والتقنية والاقتصادية والمعلوماتية. أب أن التربية البيئية تسعى بناء على هذا المفهوم تتمية الاتجاهات والميول والأخلاقيات البيئية المسئولة نحو البيئة وقضاياها و بناء السلوكيات والمهارات البيئية الايجابية وبهذا لم تعد التربية البيئية مجرد معلومات تدرس عن مشكلات البيئة كالتلوث وتدهور الوسط الحيوي أو استنزاف الموارد ولكنها

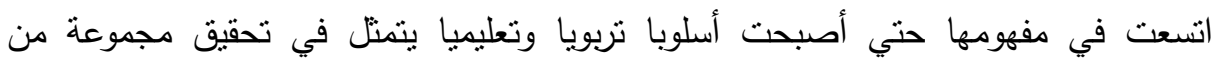
الاهداف العامة. وقد أكد أنباع أنصار تنار الفلسفة الأخلاقية المعاصرة علي أنه لن يحصل تقدم في إنهاء الأزمة البيئية، إلا إذا حدث تحدً للمعايير الأخلاقية للمركزية البشرية ووسعنا قاعدة البهارة الاعتبارية الخلقية لتشمل الكائنات غير البشرية، فكما أن الإنسان اليوم ملزم خلقياً وقانونياً

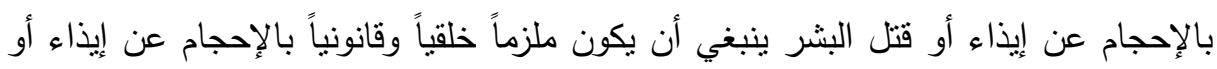

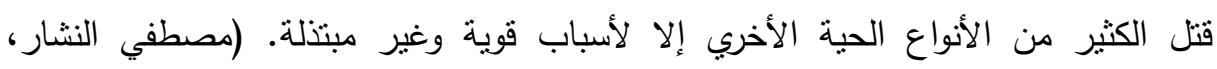

وتحتاج البشرية إلي أخلاق إجتماعية عصرية ترتبط باحترام البيئة، ولا يمكن أن نصل إلي هذه الأخلاق إلا بعد توعية حيوية توضح للإنسان مدي ارتباطه بالبيئة وتعلمه أن حقوقه 
في البيئة يقابها دائماً واجبات نحو البيئة، فليست هناك حقوق دون واجبات. (محمد إسماعيل

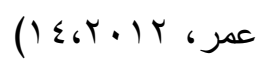

وفي ظل العالم المتتامي المعرفة، وتحديات القرن الحادي والعثرين، وماتفرضة على دئ

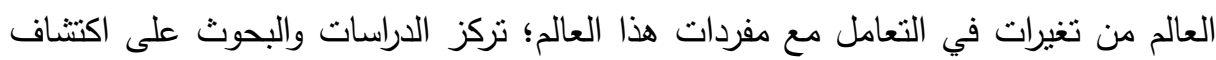
قدرات الفرد العقلية، خاصة تلك التي تساعده في مواجهة مشكلات الحياة، وقضاياها وفي ذلك متردات

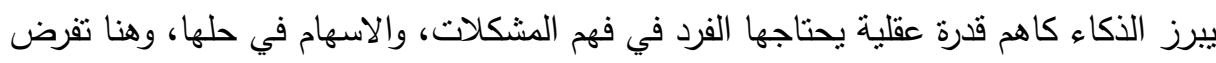

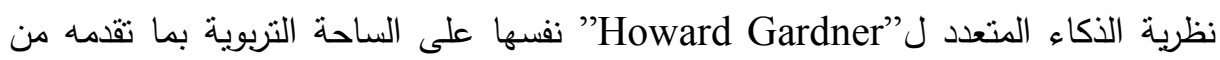
فلسفة تربوية تقوم على مبدأ تعدد قدرات المتعلم؛ الامر الذي يستلزم مخاطبة تلك التعددية

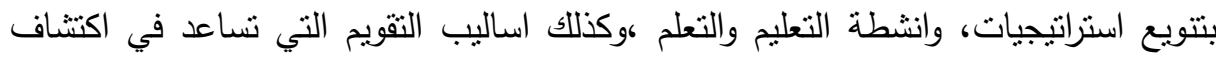
ذكاءات الطلاب، وتتميتها، واستغلالها في التعلم من اجل الفهر. (اميرة محمد أبا زيد،

\section{And ILan}

إن كل ما يشهذه عصرنا الحالي من تغيراتٍ بيئيةٍ عميقةٍ ومشكلاتٍ بيئيةٍ واسعةٍ ومعقدة

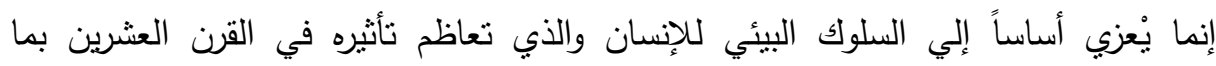

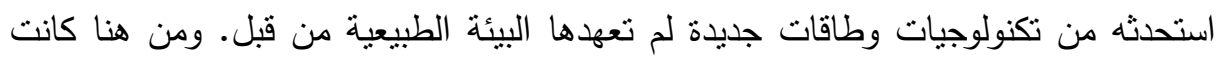

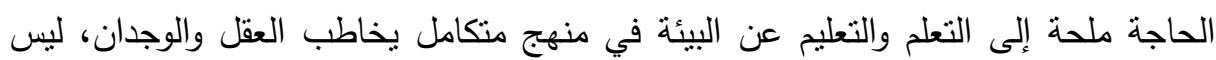
فقط مجرد سرداً للمعلومات في مجال البيئة، ومن هنا كانت الحاجة إلى تبني برامج في التربية البيئية بمعناها الثنامل لتتمية الأخلاقيات والذكاء البيئي.

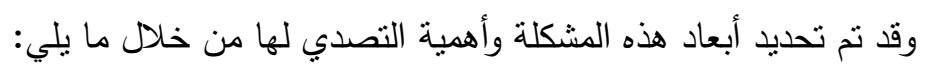
أولاً: الإطلاع على البحوث والإراسات السابقة: في مجال الأخلاقيات البيئية: أكدت العديد من الدراسات منل دراسة (إيناس محمد لطفى

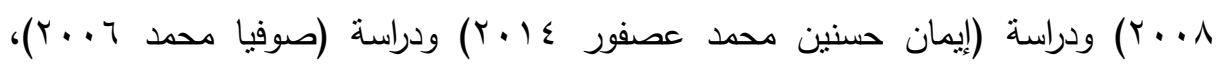

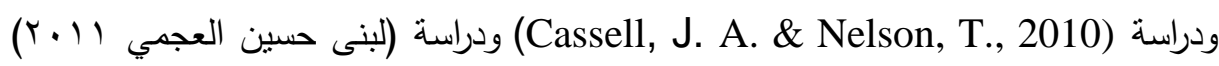

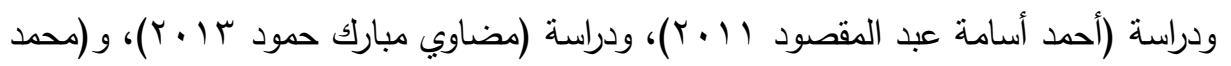

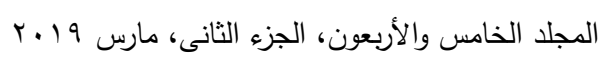




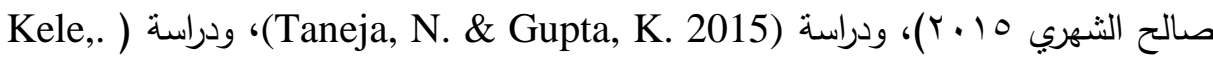
(KARAKAYA, F., \& YILMAZ, M. 2017) ودراسة)، ودراسة)، ودردة) 2016 ودراسة (Cassell, J. A., \& Nelson, T., 2010)، ودراسة عikhat, Khan, Z) (2017، ودراسة (Perrin, J. L. 2017) على تدني مستوى الأخلاقيات البيئية لدي عينات مختلفة من التلاميذ وضرورة تتميتها.

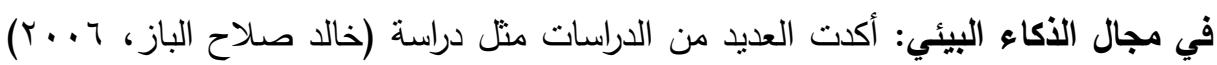

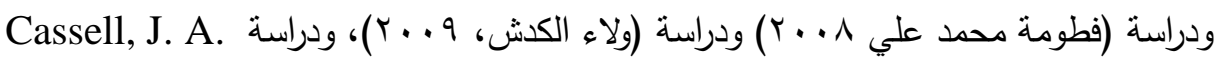

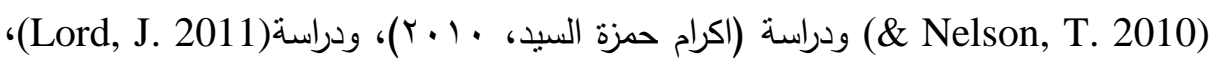
ودراسة (Tirri, K. \& Nokelainen, P. 2012)، ودراسة Meyers, E. M. \& Bittner) (R. 2012 February)

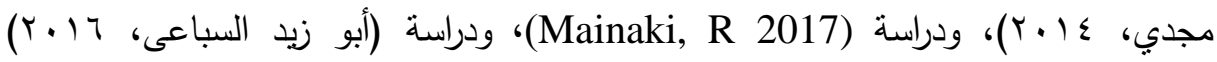

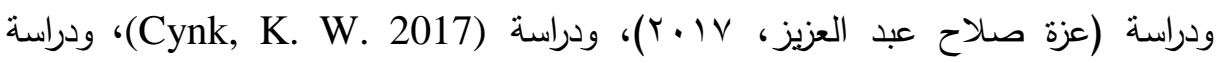
(Mainaki, R. \& Etle 2018) مراحل مختلفة، وعلى حد علم الباحثون توجد ندرة في الدراسات التي تتتاول تتمية الذكاء البيئي

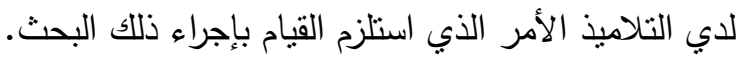
في مجال استراتيجية التعلم المتمركز حول مشكلة: أكدت العديد من الدراسات مثل دراسة

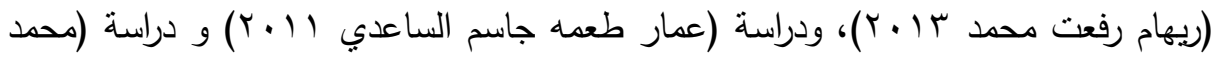

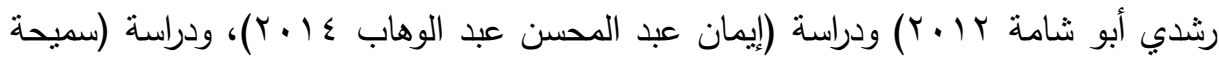

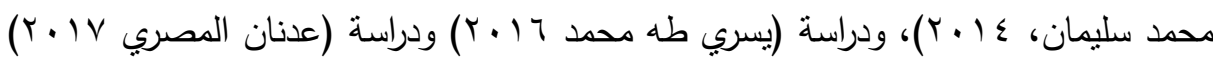
على فاعلية استخدام التعلم المتمركز حول المشكلة فى تتمية جوانب تعلم مختلفة، إلا أنها لم تنتاول الأخلاقيات أو الذكاء البيئي، فربما تسهم فى تتميتهما. في مجال البرامج الإثرائية: اهتمت العديد من الدراسات التربوية في المواد الدراسية بصفة عامة على أهمية تضمين المناهج العديد من الأنشطة التعليمية والاهتمام بها لإثراء المواقف لهن 
التدريسية وذلك لتحقيق الأهداف المرجوة مثل دراسة (خالد عبداله الحموري 9 .. ب)، ودراسة إيمان حسن محمد ابوسعدية (ع ( ب r). ثانياً: الاراسة الاستطلاعية: قام الباحثون بإجراء دراسة استطلاعيةعلي عينة من التلاميذ بمرحلة التعليم الأساسي للتعرف علي مستوي الأخلاقيات البيئية حيث نم تطبيق مقياس (أحمد

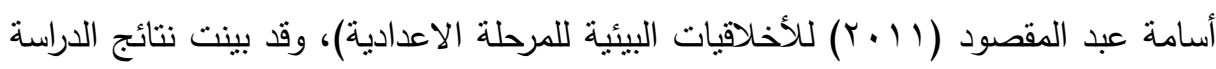
الاستطلاعية الآتي: أن حوالي (^^^\%) من عينة التلاميذ لديهم قصور في مسنوى الأخلاقيات

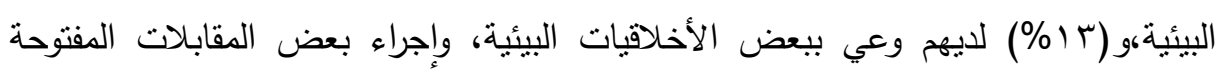

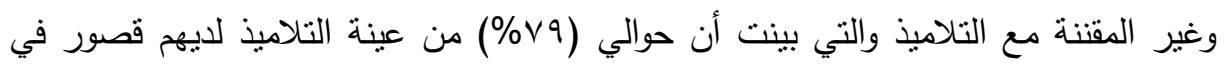

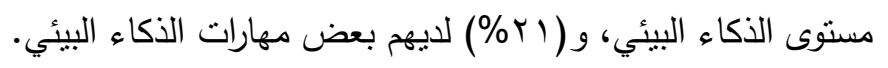

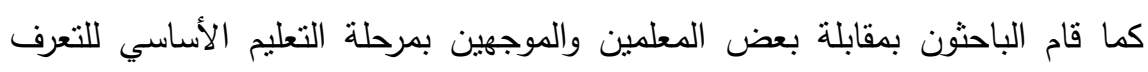

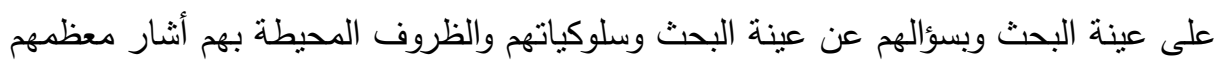

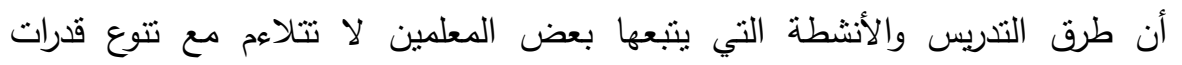

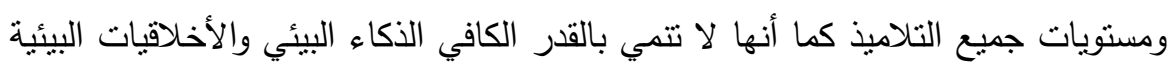
وهذا ما استتجه الباحثون من خلال ملاحظة الأداء التدريسي لعدد من المعلمين ومناقثنة عدد من الموجهين عن أساليب التعليم والتعلم والأنشطة المتبعة في التدريس. أثار بعض المعلمين والموجهين الذين نم مقابلتهم في المدارس التي نم زياراتها إلى أن

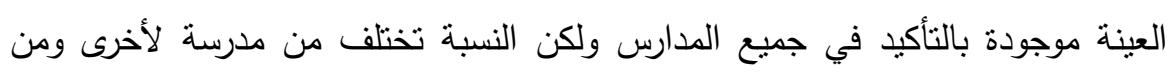

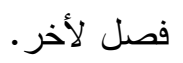
تأسيساً علي ما سبق تتمثل مشكلة البحث في وجود تدنى وضعف في مستوي الذكاء البيئي وقصور في مستوى الأخلاقيات البيئية لدى تلاميذ المرحلة الاعداديه. 


\section{أسئلاً البهيش}

تم صياغة مشكلة البحث في السؤال الرئيسي التالي: "ما فعالية البرنامج الإثرائي القائم علي استراتيجية التعلم المتمركز حول مشكلة علي تتمية بعض الأخلاقيات والذكاء البيئي لدى

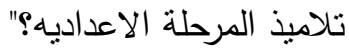
ويتفرع عن هذا السؤال الأسئلة التالية:-

ا ـ ما الأخلاقيات البيئية التي ينبغي تتميتها لاى تلاديذ المرحلة الاعداديه؟ r. ما دهارات الذكاء البيئي التي ينبغي تتميتها لدى تلاميذ المرحلة الاعداديه؟ r. ما التصور المقترح للبرنامج الإثرائي القائم علي استراتيجية التعلم المتمركز حول مشكلة لهاءئ لاع تلاميذ المرحلة الاعداديه؟ ع. ما فعالية البرنامج الإثرائي علي تتمية بعض الأخلاقيات البيئية لدى تلاميذ المرحلة الاعداديه؟ ه. ما فعالية البرنامج الإثرائي علي تتمية مستوي الذكاء البيئي لاى تلاميذ المرحلة الاعداديه؟

\section{هزوضر الهيش}

ا • يوجد فرق دال إحصائياً بين متوسطي درجات تلاميذ المجموعة التجريبية في مقياس

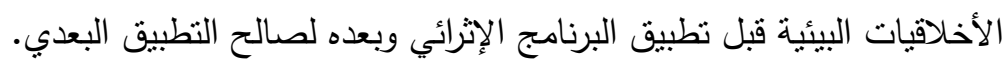

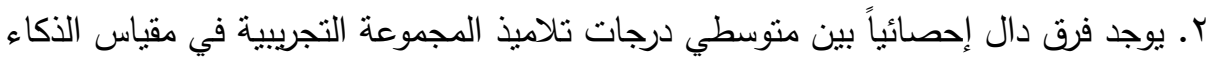
البيئي قبل تطبيق البرنامج الإثرائي وبعده لصالح التطبيق البعدي.

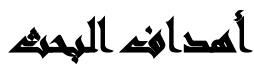

استهدف البحث الحالي: تتمية الأخلاقيات والذكاء البيئي لاى تلاميذ المرحلة الاعداديه من خلال تصميم البرنامج الإثرائي القائم على استراتيجية التعلم المتمركز حول مشكلة. 


\section{أهمية المهمث}

ا. لفت انتباه مطوري المناهج وطرق التدريس والمعلمين لأهمية الذكاء البيئي والأخلاقيات

البيئية، وضرورة مراعاثتميتهم من خلال المواد الدراسية المختلفة.

r. توجيه نظر المسئولين والقائمين علي إعداد برامج المعلمين في كليات التربية إلي أهمية تضمين الأخلاقيات البيئية و مهارات الذكاء البيئي بمقررات إعداد المعلمين.

r. توجيه نظر التربوبين والمعلمين إلي ضرورة توفير بيئات تعلم تشجع على تتمية مستوى بهين الذكاء البيئي ومستوى الأخلاقيات البيئية.

ع. تقديم برنامج للمعلم يمكن الاسترشاد به في تتمية مستوي الذكاء البيئي ومستوى الاهئه الأخلاقيات البيئية لدى تلاميذ المرحلة الاعداديه. ه. تقديم مقياس لقياس مستوى الأخلاقيات البيئية لدى تلاميذ المرحلة الاعداديه. 7. تقديم مقياس لقياس مستوي الذكاء البيئي لدى تلاميذ المرحلة الاعداديه.

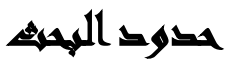

الحدود المكانية: نم تطبيق البحث على عينة من تلاميذ المدارس الاعداديه بإدارة التبين

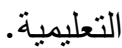
الحدود الزمنية: نم نطبيق البحث خلال الفصل الدراسي الأول في العام الدراسي (1) •؟$\cdot\left(a^{2} \cdot 19\right.$ الحدود البشرية: نم تطبيق البحث على عينة من تلميذات الصف الثاني الاعدادى.

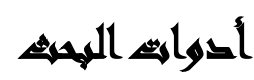

ا ـ البرنامج الإثرائي القائم علي التعلم المتمركز حول مشكلة. (إعداد الباحثون). r. مقياس الأخلاقيات البيئية (إعداد الباحثون). r. مقياس الذكاء البيئي (إعداد الباحثون). 


\section{هنهمج الهمبش}

استخدم البحث المنهج شبه التجريبي: لتجريب استخدام البرنامج الإثرائي، وقياس

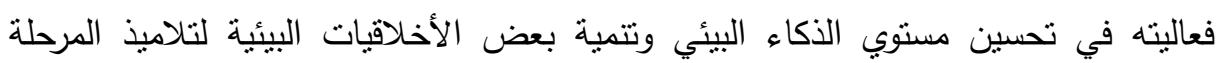
الإعدادية.

إن التصميم شبه التجريبي الذي يتبعه البحث هو التصميم القائم على مجموعة تجريبية واحدة، وذلك لأنه التصميم الأنسب للتعامل مع متغيرات البحث، حيث أن أنثطة البرني البنامج إثرائية وغير مرتبطة بالمقررات الدراسية، كما أنه قائم علي استراتيجية محددة وهي استراتيجية

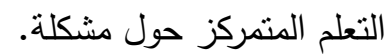

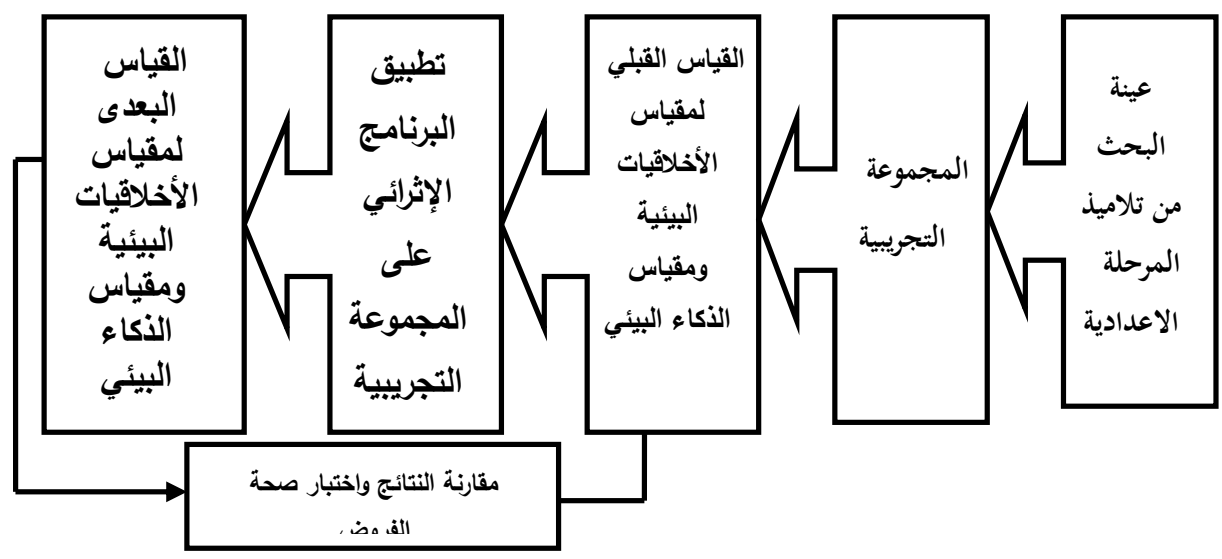

\section{همطلحايت المهيث}

البرنامج الإثرائي Enrichment Program: "هو جزء من البرنامج العام يقدم للتلاميذ

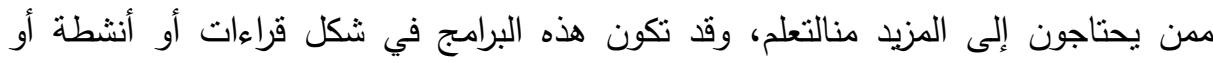

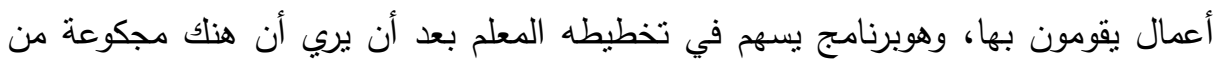

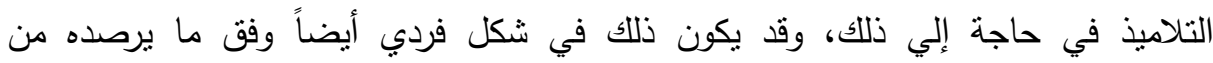


ملاحظات علي تلاميذه، ويقدم البرنامج الإثرائي بطريقة موازية لتدعيم المناهج المنفذة لتحقيق

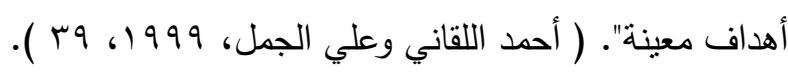

الأخلاقيات البيئية Environmental Ethics: "هي مجموعة من المعايير والمبادئ (القواعد) التي توجه الفرد في سلوكه نحو التعامل مع مكونات البيئة بشكل مناسب (لا يضر

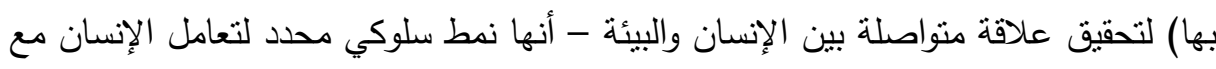

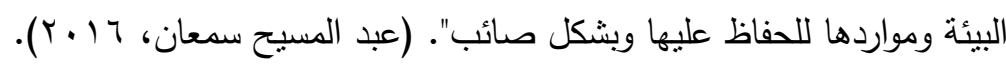
الأكاء البيئي Environmental intelligence: يُعرف بانه القدرة علي ايجاد العلاقات بين عناصر البيئة ومواردها والموضوعات المرتبطة بالطبيعة، والمقارنة بين مكوناتها من خلال الادوات والمعينات المختلفة، ويتحدد فى قدرة الفرد على التعرف والتمييز والمقارنة والتصنيف للغلاف الحيوى والأشياء والظوهر الموجودة فى الطبيعة. (هوارد جاردنر: (OT, T...O

Problem Centered Learning إستراتيجية التعلم المتمركز حول المشكلة Strategy

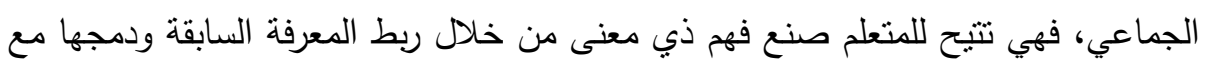

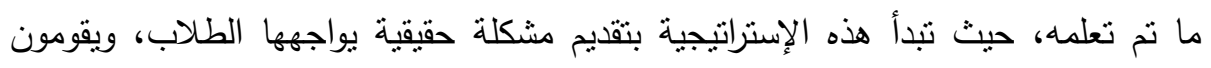

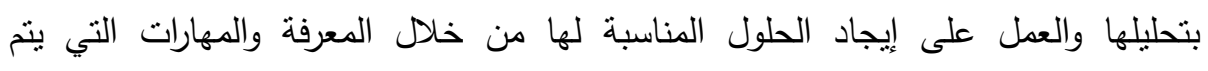
اكتسابها، وتتكون هذه الإستراتيجية من ثلاثة عناصر أساسية هي : المهام، والمجموعات المنات

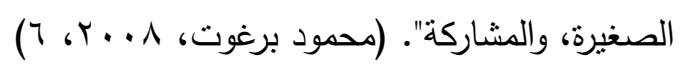

\section{الإطار اللنظليه}

مفهوم أخلاقيات البيئة: - يعرفها (ألدليوبولد) بأنها أخلاق تبحث فى علاقة الإنسان بالأرض والحيوان والنباتات التي

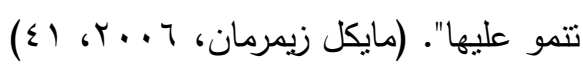


- كما تعرف بأنها "التزام من قبل الأفراد قائم على الوعي والفهم للقضايا والمشكلات البيئية، مما يجعلهم ينتهحون سلوكيات بيئية تتم عن المسئولية تجاه البيئة للمحافظة عليها

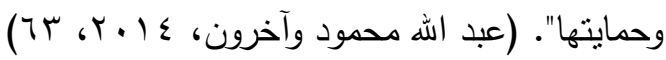

$$
\begin{aligned}
& \text { دراسات تتاولت الأخلاق البيئية منها: }
\end{aligned}
$$

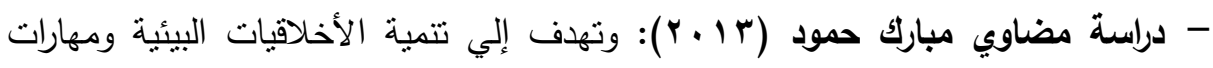
اتخاذ القرار لدي طلاب جامعة قطر من خلال اعداد برنامج قائم علي تكنولوجيا التعليم الالكتروني، وبتصميم البرنامج وتجربته أثبت فعالية كبيرة في تتمية الأخلاقيات البيئية

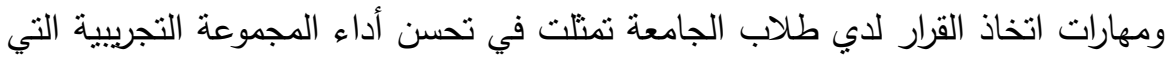
درست البرنامج علي مقياس الأخلاقيات البيئية ومقياس مهارات اتخاذ القرار مقارنة بالمجموعة الضابطة. - دراسة (Taneja, N. \& Gupta, K. 2015): هدفت التعرف على ما تعنيه الأخلاقيات البيئية، وأهية الحاجة إلى التثقيف في مجال الأخلاقيات البيئية وغرسها من أجل خلق إدراك موجه نحو البيئة. والحاجة إلى تجاوز التركيز على مجرد التوعية بالقضايا

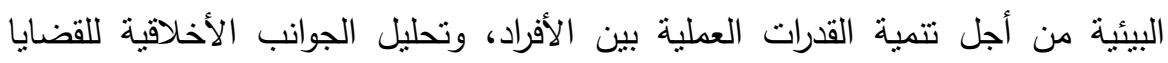
البيئية واتخاذ قرارات بشأن الإجراءات.

- دراسة (Kaur, M., Kang, T. K., \& Sharma, S. 2016) هدفت مقارنة الأخلاقيات البيئية بين الأولاد والبنات المراهقين في المناطق الريفية والحضرية في مقاطعة

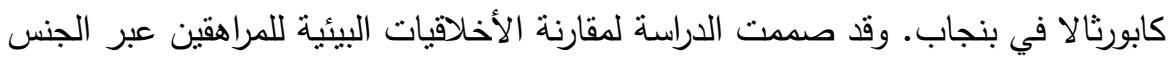
واللغة. وكثفت الفروق بين الجنسين أن الفتيات يملكن أخلاقيات بيئية أكثر مقارنة بالفتبان. وفي الفروق المحلية، تبين أن المراهقين الحضريين أكثر حساسية من الناحية البيئية مقارنة بالمراهقين في المناطق الريفية.

- دراسة (Nikhat, Khan, Z. 2017) استهدفت بناء مقياس الاتجاه نحو الاخلاق البيئية والتحقق من صدقه من خلا تقييم موقف المعلمين تجاه الأخلاق البيئية وتطوير الإهاه أخلاقياتهم في حالة عدم الاهنمام بها. بعد اتحليل النهائي لمواقف مقياس الأخلاقيات

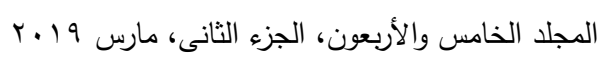


البيئية، تم الاحتفاظ بعدد (ך؟) بنداً، ومن بين هذه البنود هناك (عץ) عبارة إيجابية

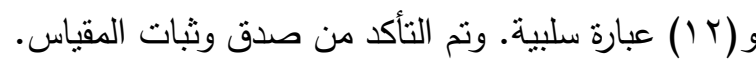

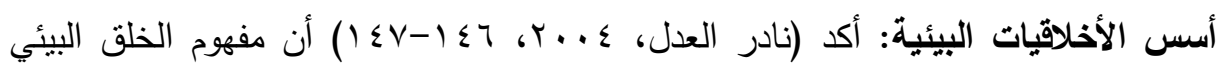

$$
\text { يقوم على عدة أسس منها ما يلي: }
$$

• ضرورة الأخذ والعطاء في علاقة الفرد بالمجنمع، وفي علاقتهما بالبيئة.

• • الفهم بكيفية الاستخدام الأمتل للموارد الطبيعية دون الإضرار بالبيئة.

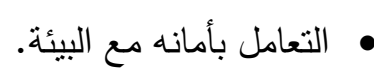

• توفير مشاعر العطف بين الناس ليعيشوا في وفاق مع بعضهم ومع البيئة.

$$
\text { • تحقيق الانسجام والتوافق مع البيئة. }
$$

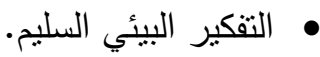

• الأخذ في الاعتبار الاثتراطات والاعتبارات البيئية في التتمية المستدامة.

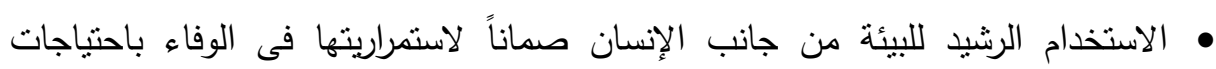

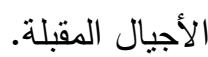

$$
\text { • • الإيمان بمدى فائدة الموارد الطبيعية للإنسان والكائنات الحية. }
$$

• قيام الأخلاق الإنسانية على العدالة الاجتماعية بالنسبة لجميع الأفراد.

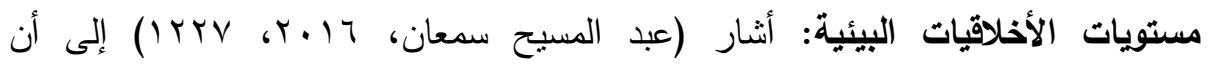

$$
\text { الأخلاقيات البيئية تقسم إلى ثلاث مستويات وهى كالتالى الإنيات }
$$

الأول: المستوي سطحيـ (Shallow): يتصف هذا المستوي بالتمركز حول الإنسان وفيه تفرض بعد القيود علي تعامل الإنسان مع البيئة بشرط الا هالان (Anthropocentrism) تتتخل هذه القيود في مصالح الإنسان، ويدعو هذا المستوي للتعقل في التعامل مع البيئة.

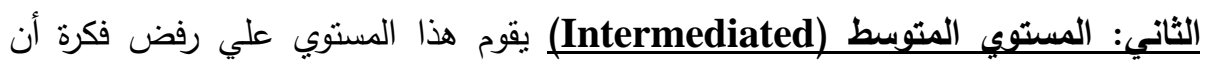

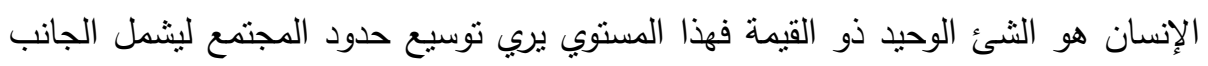

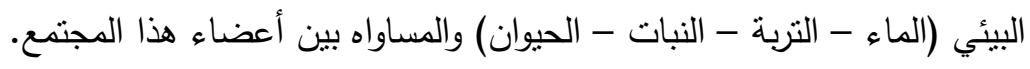


الثالث:المستوي العميق (Deep): هذا المستوي يدعو إلي التمركز حول الجانب الايكولوجي للبيئة (Ecocentrism) وبالتالي فإن أخلاقيات البيئة هنا قائمة علي تقدير البيئة وإحترامها بإعتبارها ذات قيمة في حد ذاتها وليس تقديرها من خلال علاقتها بالإنسان ومصالحة. مفهوم الأكاء البيئي Environmental Intelligence: يُعرف على أنه " قدرة الفرد على التعرف على عناصر البيئة الطبيعية والتكيف معها سواء بالاستجابة لها أوبتعديلها بما يتواءم مع حياته الاجتماعية،واستشعاره لمشكلاتها واستعداده للمساهمة في حلها، ووعيه بدوره

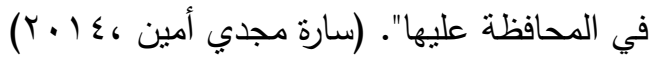
تطور مفهوم الذكاء البيئي: تطور مفهوم الذكاء البيئي من فكرة مؤسسها العالم جاردنر الذى أضافه كأحد الذكاءات المتعددة لدى الفرد والذي أطلق عليه (Gardener) إلى المنظور الأوسع الذي تنباه العالم جولمان (Naturalintelligence) إليه لمواجهة المشكلات البيئية ومعرفة الآثار البيئية لسلوك الإنسان إلى البى منظور أكثر انساعاً تعدى مجرد معرفة الانسان للآثار البيئية لسلوكياته المختلفة نحو البيئة مثل العالم .(Tirri, K. \& Nokelainen) و (McCallum) و (Bowers, C. A.) أبعاد ومكونات الأكاء البيئي: أنشار (Tirri, K. \& Nokelainen, P. 2012) إلى ثلاثة أبعاد للذكاء البيئي فى مقياس وهي: حب الطبيعة، الحفاظ على الطبيعة، عادات المستهلك

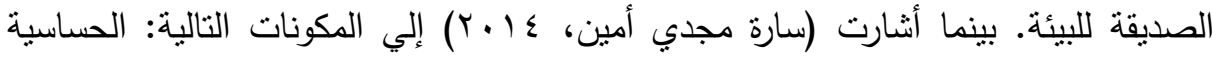
البيئية، الإدراك البيئي، الملاحظة البيئة، التصنيف البيئي، التواصل البيئي.

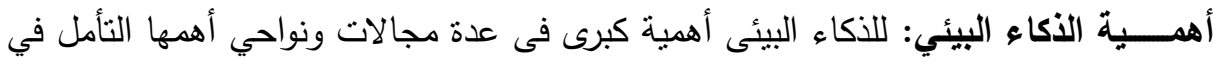
الطبيعة، ارتباط الذكاء البيئي بعناصر البيئة، حل المشكلات البيئية، المناهج الدراسية، الآثار البيئية للمنتجات، الزراعة، القيادة، العمل والمتعة، عمليات النتبؤ والنوقعات. وقد تتاولت بعض الدراسات مفهوم الذكاء البيئي ولكن من وجهات نظر مختلفة ومنها:

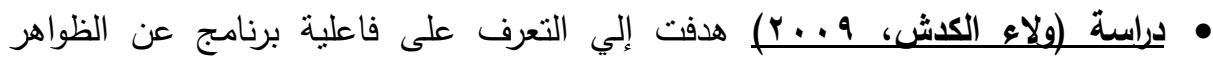
الطبيعية لتتمية الذكاء الطبيعي لطفل الروضة. توصلت الباحثة إلي مجموعة من النتائج

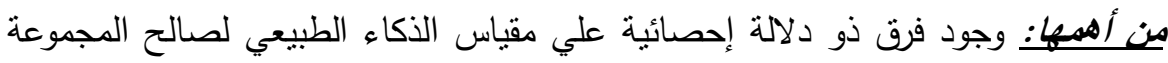

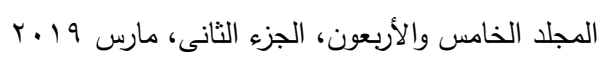




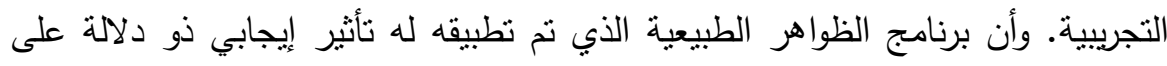
تتمية الذكاء الطبيعي للمجموعة التجريبية، وقد أوصت الدراسة إلي الاهتمام بالذكاء الطبيعي وتتميته عند الأطفال له عظيم الأثر في حل كثير من المشكلات.

دراسة (Meyers, E. M. \& Bittner, R. 2012): أوضحت كيف أن العوالم الافتراضية ندعم الذكاء البيئي فهناك نهج ناشئ لتعليم الشباب حول الاستدامة وهو

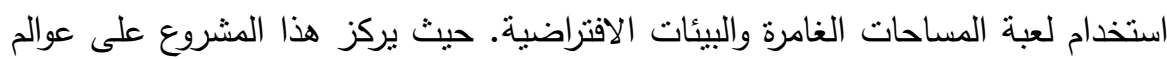

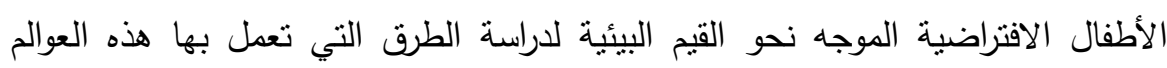
كوسائل لتعليم الاستدامة.

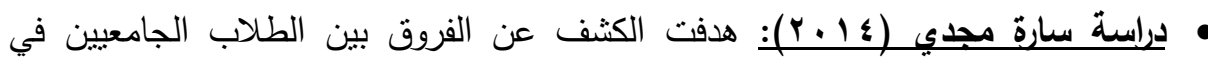
الذكاء الطبيعي حسب الجنس والتخصص من طلاب جامعة قناة السويس.

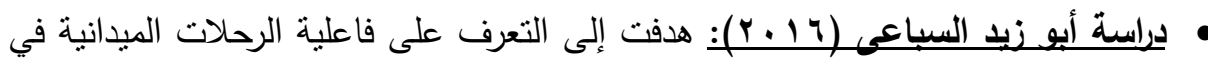
تتمية الذكاء الطبيعي لاي طلاب شعبة الجغرافيا بكلية التربية، أسفرت النتائج عن وجود فرق ذو دلالة إحصائية بين منوسطي درجات المجموعة التجريبية في التطبيق القبلي

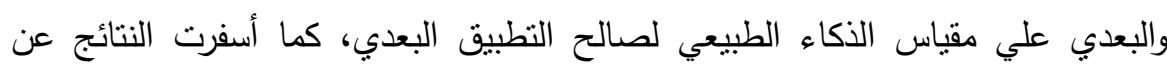
وجود فرق ذو دلالة إحصائية بين متوسطي درجات المجموعة التجريبية في التطبيق القبلي والبعدي علي بطاقة ملاحظة الأداء العملى لصالح التطبيق البعدي.

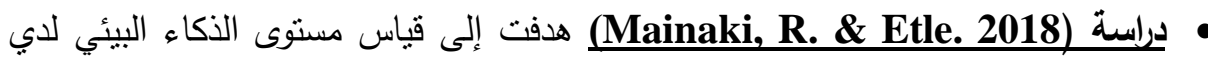

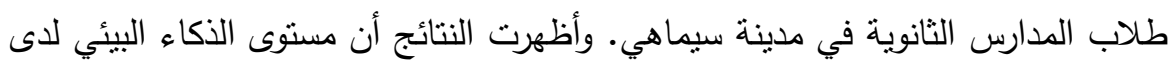

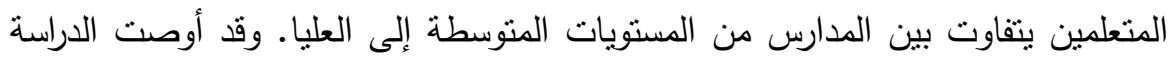

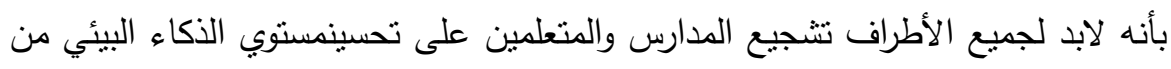
خلال برامج مختلفة في المدارس قائمة على جهود الحفاظ على البيئة.

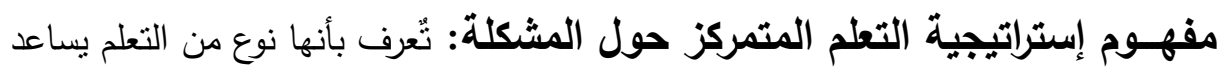
المتعلمين على فهم ما يتعلموه وبناء معنى له، وينمي النقة في قدراتهم على حل المشكلات.

(Wheatly, 1991, P.10) 
مراحل إستراتيجية التعلم المتمركز حول المشكلة: تتكون هذه الإستراتجية من ثلاثة مراحل

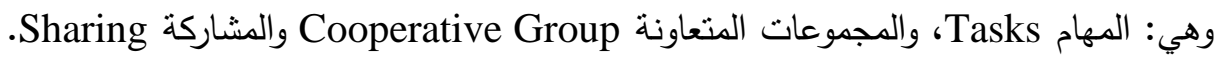
حيث يبدأ التدريس بهذه الإستراتيجية بمهمة Task تتضمن موقفًا مشكلاً يجعل المتعلمين

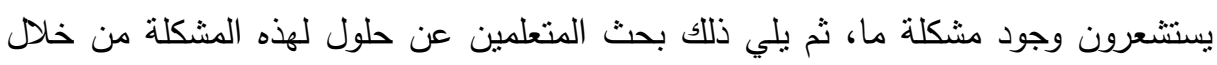

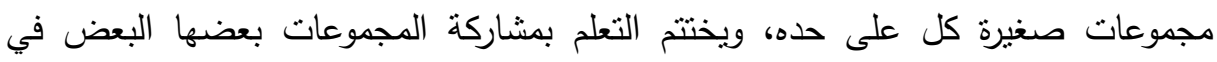

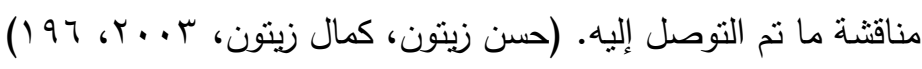
خصائص إستراتيجية التعلم المتمركز حول المشكلة: من الخصائص التي تميز هذه

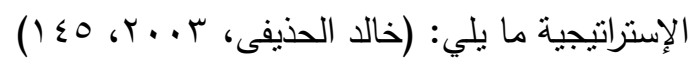

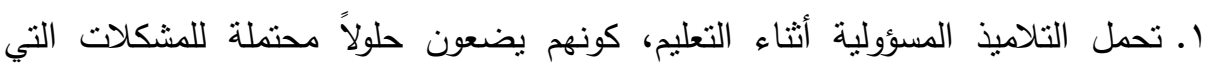
تواجهرم، ويستخدمون المصادر المتتوعة للمعلومات التي يتوقعون أن تساعدهم. r. محور التدريس بهذه الإستراتيجية يعتمد على مهارة تصميم المشكلة، بطريقة تسمح بالبحث

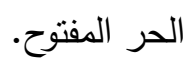
r. تساعد هذه الإستراتيجية على تتمية مفهوم التعلم التعاوني، كما تتمي كثيرًا من المهارات

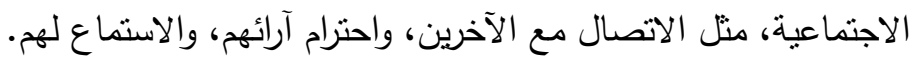

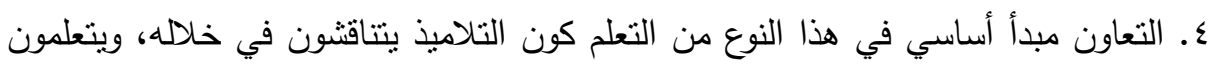
سويًا ويساعد بعضهم بعضيًا في الحصول على فهم لما يتعلمونه، ومن ثم يتم تطبيقه. ه. لا يشعر التلميذ بتقييد على أفكاره أو آرائه، بل بشعر بحرية في في التعبير دون نسلط من

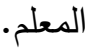

7. يقتصر دور المعلم في هذا النموذج على التوجيه والإرشاد لعطلية التعلم.

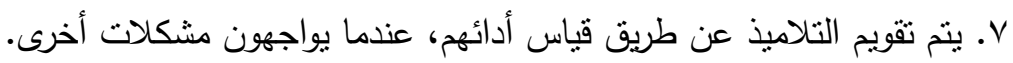

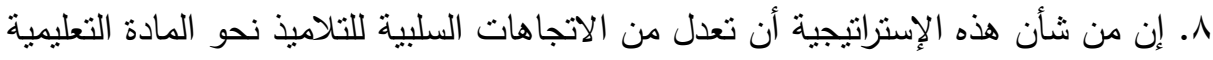

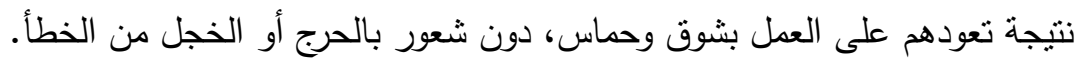


دراسات تتاولت إستراتيجية التعلم المتمركز حول المشكلة:

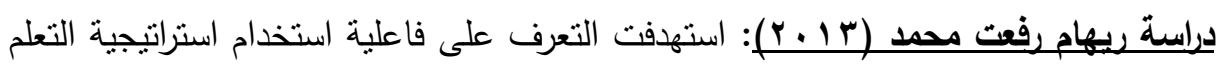
المتمركز حول المشكلة فى تدريس وحدة" الإنسان والبيئة فى بلدى " بمنهج الدراسات

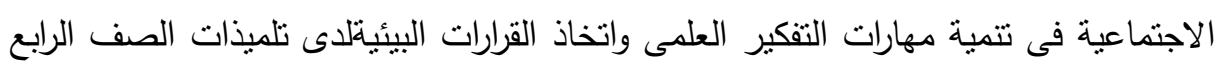
الابتدائى، وقد أثنتت نتائج البحث فاعلية التدريس باستخدام استراتيجية التعلم المتمركز حول لفئل مشكلة. دراسة سمبحة محمد سليمان (؟ ب. r): هدفت إلى الكثف عن فعالية استخدام استراتيجيتي

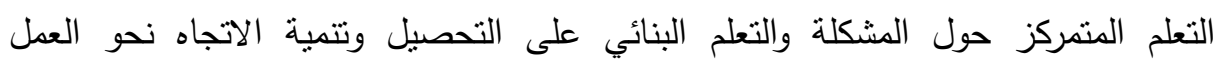

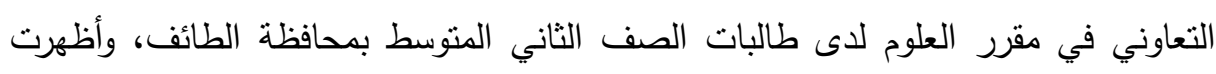
نتائج الدراسة ارتفاع مستوى التحصيل والاتجاه نحو العمل التعاوني لدى طالبات المجموعتين التجريبينين مقارنة بالمجموعة الضابطة. دراسة إيمان عبد المحسن عبد الوهاب (؟ ب ب): هدفت إلى التعرف على فاعلية استخدام

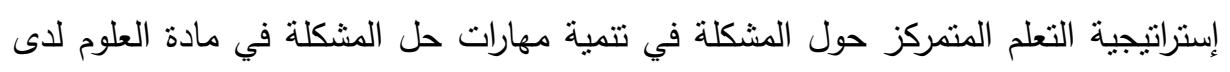

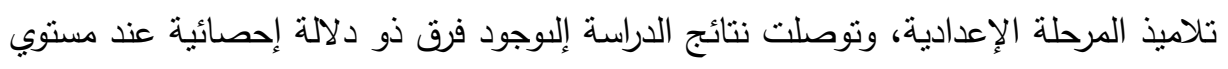

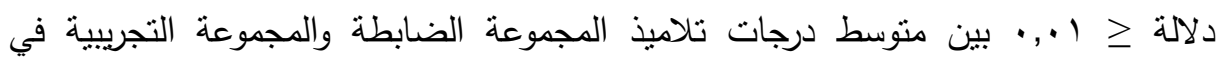

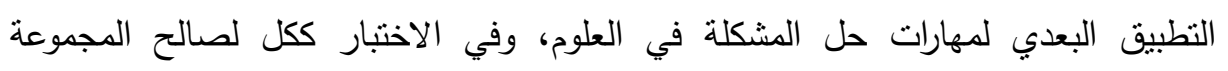
التجريبية، ويثير ذلك إلى فاعلية استخدام إستراتيجية التعلم المتمركز حول المشكلة في تتمية التئية مهارات حل المشكلة.

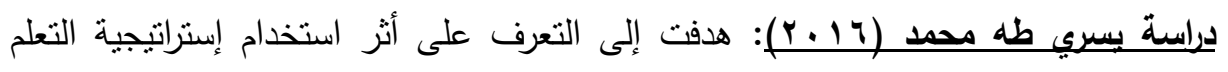
المتمركز حول المشكلة في تتمية التحصيل والتفكير التأملي والدافعية نحو تعلم العلوم لدى الدى لتئي تلاميذ الصف الثاني الإعدادي، وتوصلت الدراسة إلى وجود فروق دالة إحصائياًيين منوسطي تئي درجات تلاميذ المجموعة التجريبية والمجموعة الضابطة لصالح تلاميذ المجموعة التجريبية في كل من: الاختبار التحصيلي، واختبار التفكير التأملي، ومقياس الدافعية نحو تعلم العلوم. البرامـج الإثرائيـة: الإثراء هو إدخال تعديلات أو إضافات على المناهج العادية للطلبة

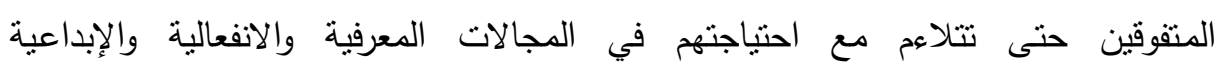


والحسحركية، دون أن يترتب على ذلك اختصار للمدة الزمنية اللازمة عادة للانتهاء من

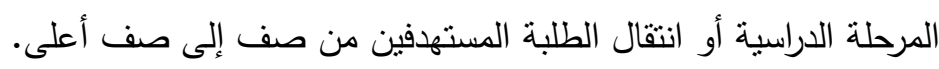

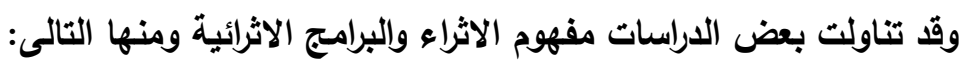

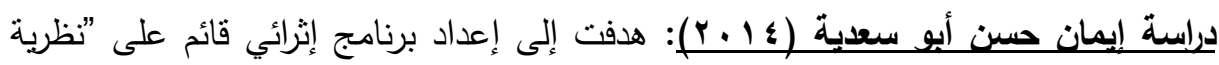

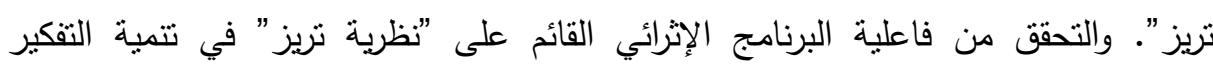

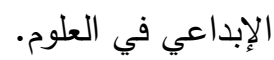

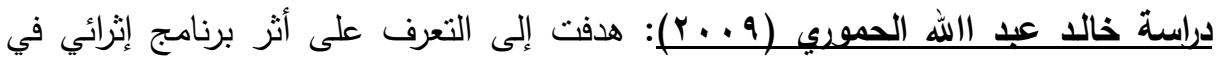
التربية البيئية في تتمية مهارات التفكير الابتكاري والتحصيل لدى الطلبة الموهوبين في منطقة

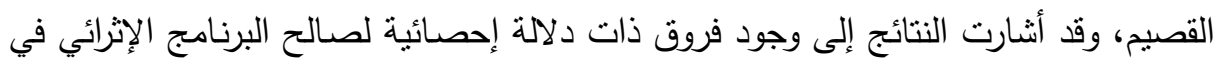

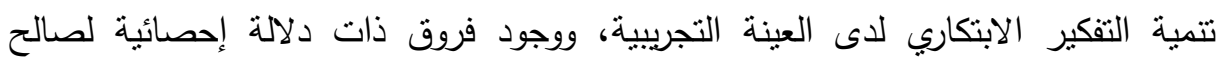
البرنامج الإثرائي في تتمية التحصيل في التربية البيئية لادى العينة التجريبية.

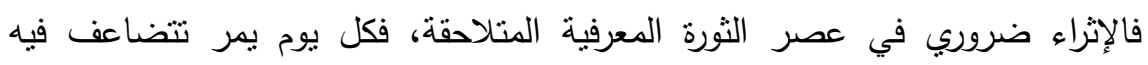
المعرفة العلمية ويكون الغرض من الإثراء هنا هو مواكبة التطور العلمي الحديث واكتساب

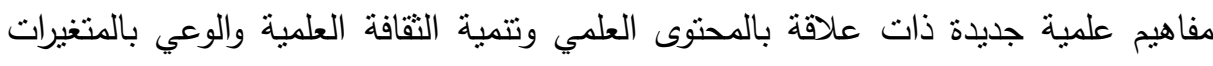

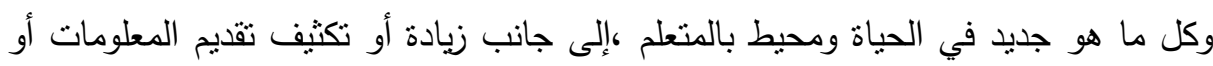

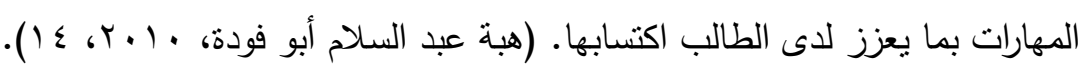

\section{إلجراءائ الهمهث}

\section{للإجابة عن السؤالين الأول والثاني للبحث:}

- ما الأخلاقيات البيئية التي ينبغي تتميتها لاعى تلاميذ المرحلة الاعداديه؟ - ما مهارات الذكاء البيئي التي ينبغي تتميتها لدى تلاميذ المرحلة الاعداديه؟

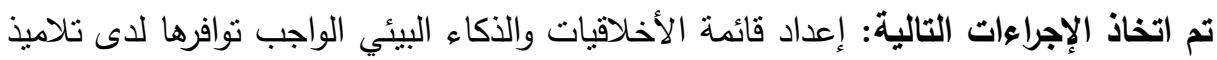

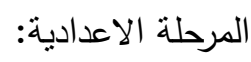


الهدف من إعداد القائمة: - إن

• تحديد الأخلاقيات البيئية الواجب توافرها وتتميتها لدى تلاميذ المرحلة الاعدادية.

• •حديد مهارات الذكاء البيئي الواجب توافرها وتتميتها لدى تلاميذ المرحلة الاعدادية.

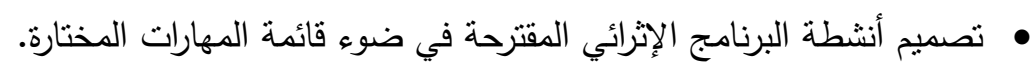

• بناء مقياس الأخلاقيات البيئية في ضوء قائمة المهارات المختارة.

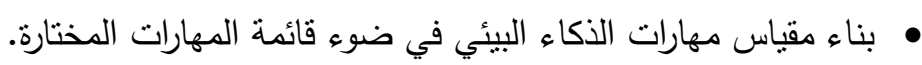

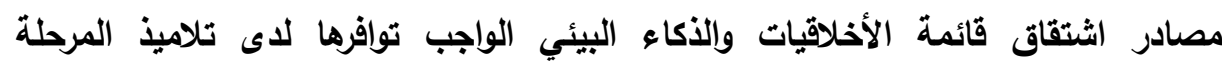

الاعدادية: نم الاعتماد في اشتقاق القائمة علي العديد من المصادر تمثلت في الآتي:

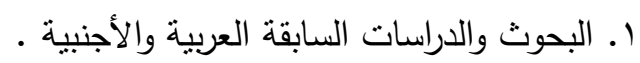

r. خصائص نمو وسمات وحاجات تلاميذ المرحلة الاعدادية.

r. الكتب والقراءات والمراجع الخاصة بالأخلاقيات والذكاء البيئي.

ع. القضايا والمشكلات البيئية المرنبطة بالأخلاقيات والذكاء البيئي.

ه. آراء الخبراء والمتخصصين فى التربية البيئية والمناهج وطرق التدريس وعلم النفس.

وفيما يلي عرض تلك المصادر بالتفصيل:

ا ـ البحوث والدراسات السابقة العربية والأجنيبة: قد ساهمت البحوث والدراسات السابقة في بالدي

تحديد واشتقاق بعض الأخلاقيات التي ينبخي تتمينها لاى تلاميذ المرحلة الاعدادية، مثل

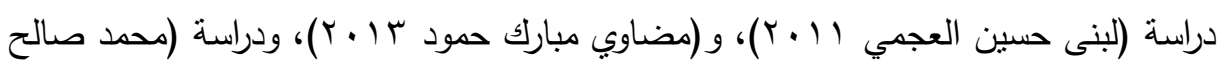

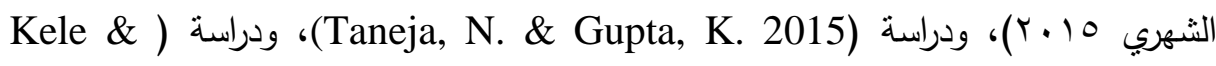
Özer, N. 2016 (Ö)، ودراسة (KARAKAYA, F. \& YILMAZ, M. 2017)، ودراسة (دراسة \& Perrin, J. Gola, B. 2017) (L.2017) وقد توصل الباحثون الي بعض الأخلاقيات من خلال هذا المصدر وهي:

$$
\begin{aligned}
& \text { أخلاقيات المياه. } \\
& \text { أخلاقيات التتوع البيولوجى. } \\
& \text { أخلاقيات الهواء (المناخ). } \\
& \text { أخلاقيات الأرض. }
\end{aligned}
$$




$$
\text { أخلاقيات التعامل مع البشر . أخلاقيات التعامل مع المرافق والممتلكات. }
$$

قد ساهمت البحوث والدراسات السابقة في تحديد واثتقاق بعض مهارات الذكاء البيئي

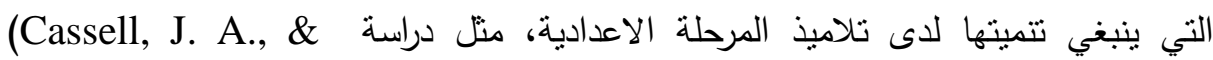
Nelson, T. 2010) (Meyers, E. M., \& Bittner, R. 2012, February)

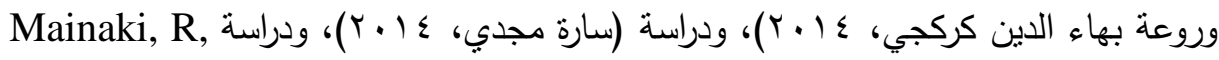

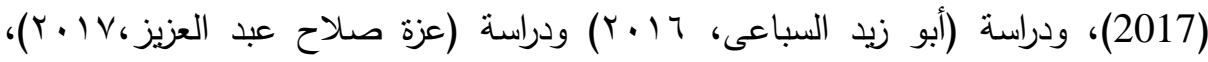
ودراسة (Cynk, K. W. 2017) ، ودراسة (Mainaki, R. \& Etle 2018)، وقد توصل الباحثون الي بعض المهارات من خلال هذا المصدر وهي: - التعرف على العالم المحيط.

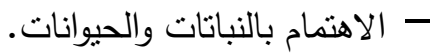

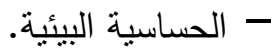

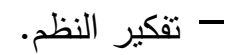
- ممارسة سلوكيات صديقة للبيئة. - التواصل البيئي.

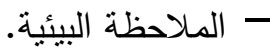

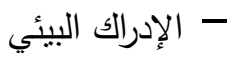

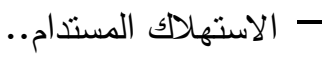

-

r. خصائص نمو وسمات وحاجات تلامبذ المرحلة الاعدادية: يطلق على مرحلة الطفولة المتأخرة"قبيل المراهقة" وهي مرحلة الإعداد للمراهقة وتمهيداً لها، وتتميز هذه المرحلة ببطء معدل النمو بالنسبة لسرعته في المرحلة السابقة، والمرحلة اللاحقة ،وزيادة التمايز بين الجنسين، وتعلم المهارات اللازمة لثؤون الحياة، وتعلم المعايير الأخلاقية والقيم وتكوين

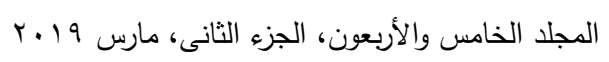


الاتجاهات والاستعداد لتحمل المسئولية وضبط الانفعالات، وتعتبر هذه المرحلة أنسب

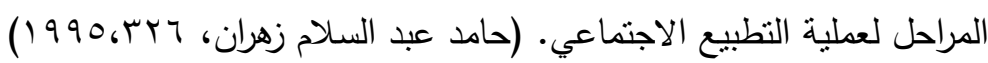

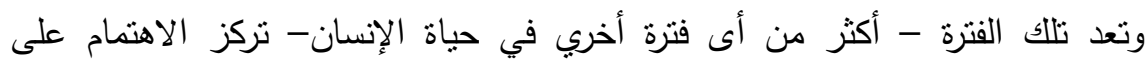
الأخلاق والقيم والمعايير، كما أن قدراتهم على التأمل والتقكير تدعم الوعى التهي الكبير بالأسئلة والاستفسارات المرتبطة بالأخلاق، كما أن الدجتمع فى عصرنا الحديث ملئ الهئ بالضغوط

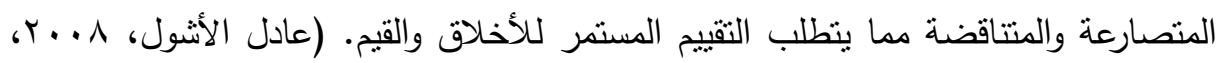

r. الكتب والقراعات والمراجيع الخاصة بالأخلاقيات والذكاء البيئي: قد ساهمت بعض الكتب

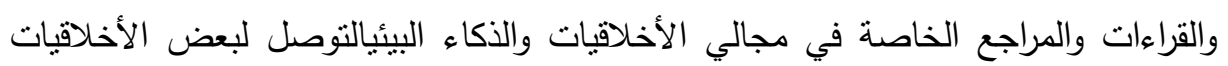

$$
\text { ومهارات الذكاء البيئي. }
$$

ء. القضايا والمشكلات البيئة المرتبة بالأخلاقيات والأكاء البيئي: تم تحديد مجموعة من القضايا والمشكلات البيئية وهي الأكثر أهمية وإلحاحاً فى ذلك العصر وارتباطياً بالأخلاقيات

$$
\begin{aligned}
& \text { والذكاء البيئي وهي كالتالي: } \\
& \text { - اختلال التوازن البيئي. } \\
& \text { - التتوع البيولوجي. } \\
& \text { - مشكلات المياه } \\
& \text { - مشكلات الطاقة. } \\
& \text { - التغير المناخي. } \\
& \text { - الاستهلالك المفرط للموارد. } \\
& \text { - المخلفات الصلبة. }
\end{aligned}
$$

وفي ضوء تلاك القضايا والمشكلات الرئيسية تم تحديد الأخلاقيات ومهارات الذكاء البيئي

$$
\text { الرئيسية والفرعية المرتبطة بهاء وفئ. }
$$

ه. آراء الخبراء والمتخصصين في التربية البيئة والمناهج وطرق التربس وعلم النفس.

الصوية الأولية للقائمة: نم عرض القائمة التي تم التوصل إليها على مجموعة من السادة

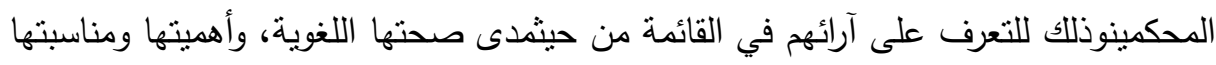


للتناميذ، ومدي ارتباط كل مهارة فرعية بالمهارة الرئيسة للذكاء البيئي، ومدي ارتباط كل خلق

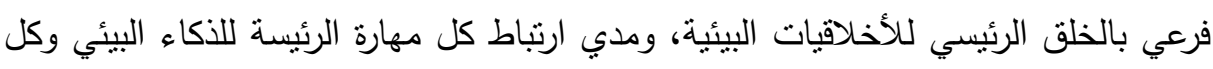
خلق بيئي رئيسيبالقضايا والمشكلات البيئية. الصورة النهائية للقائمة: تم تعديل القائمة المبدئية في ضوء آلئية آراء السادة المحمكين الذين أثناروا ارتباط الأخلاقيات ومهارات البيئي الرئيسية بالقضايا والمشكلات البيئية، والسلاهة

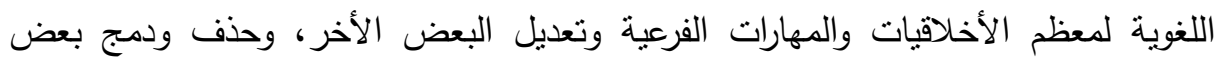

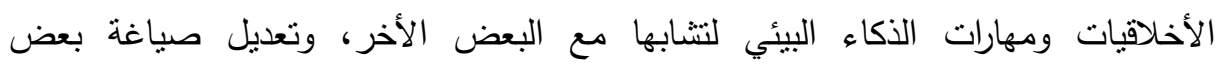
الأخلاقيات ومهارات الذكاء البيئي. كما إلى أهية القضايا البيئية وبذلك أصبحت القائمة النهائية مكونة من (سبعة) قضايا رئيسية برتبط بكل منها مجموعة من الأخلاقيات ومهارات الذكاء البيئي الرئيسية والفرعية. ويذلك بكون البحث قل أجاب عن السؤلين الأول والثاني للبحث: - ما الأخلاقيات البيئية التي ينبغي تتميتها لدى تلاميذ المرحلة الاعداديه؟

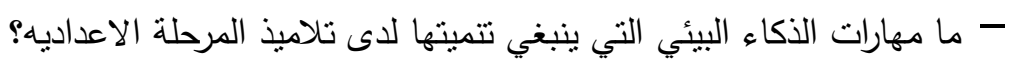
وللإجابة علي السؤال الثالث: ما التصور المقترح للبرنامج الإثرائي القائم علي استراتيجية التعلم المتمركز حول مشكلة لدى تلاميذ المرحلة الاعداديه؟ اتبع البحث الإجراءات التالية: البرنامج الإثرائي القائم علي استراتيجية التعلم المتمركز حول التئلئ

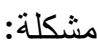
لتصميم البرنامج القائم علي استراتيجية التعلم المتمركز حول مشكلة اتبع البحث الإجراءات

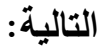
أولاً: أسس البرنامج الإثرائي المقترح: الأسس التي اعتمدت عليها البحث في بناء البرنامج: - البحوث والدراسات السابقة. - إستراتيجية التعلم المتمركز حول المشكلة. - قائمة الأخلاقيات ومهارات الذكاء البيئي. - خصائص نمو وحاجات التلاديذ بالمرحاة الاعدادية.

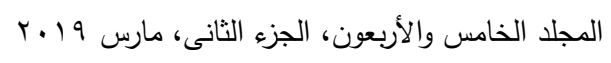


- خصائص بناء البرامج التعليمية المقترحة.

- فلسفة الإثراء.

ثانيا: الأهداف العامة للبرنامج الإثراءئي:

- الثطف العام للبرنامج: تتمية بعض الاخلاقيات ومهارات الذكاء البيئي لاى التلاميذ

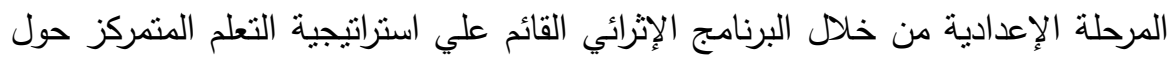

مشكلة.

- الأهداف الخاصة بالبرنامج الإثرائسي: • التعرف على بعض القضايا والمشكلات البيئية المحلية والعالمية.

• • • • المساهمة فى حل بعض المشكلات البيئية.

• • ت تمية السلوكيات الصديقة للبيئة.

• اكتشاف الآثار البيئية الخفية الناجمة عن السلوكيات الثخصية للأفراد.

• • تتمية القدرة على التأمل بالطبيعة والكائنات الحية المختلفة.

• الاستمتاع بجمال الطبيعة والتعلم منها.

• التحلي بالأخلاقيات البيئية الملائمة للتعامل مع موارد البيئة.

• • تحديد مسببات المشكلات البيئية الناتجة عن أخلاقيات غير سليمة بلئه بيئياً.

• تتمية الوعى بضرورة الحفاظ على التوازن البيئي.

• • تتمية الوعى بالعوامل التى تؤدى إلى اختلال التوازن البيئي.

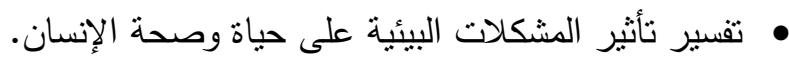

• استتناج العلاقات والروابط بين المشكلات البيئية المختلفة.

• اتخاذ القرارات السليمة بيئياً وأخلاقياً في مشكلة بيئية محددة.

• • تقدير دور الإنسان فى التصدى لمشكلات البيئة.

• • تقدير عظمة الخالق سبحانه وتعالى فى خلق الكائنات الحية.

• تقدير عظمة الخالق سبحانه وتعالى فى خلق بيئة طبيعية منوازنة.

• توظيف تكنولوجيا المعلومات في البحث عن المعلومات والحقائق البيئية.

• نتمية مهارات التفكير المختلفة مثل ( النظم- الناقد - الإبداعي - المستقبلي.......إخخ) .

المجلد الخامس والأربعون، الجزء الثانى، مارس 9 .ب 
مجلة العلوم البيئية

معهد الدراسات والبحوث البيئة - جامعة عين شمس لئة

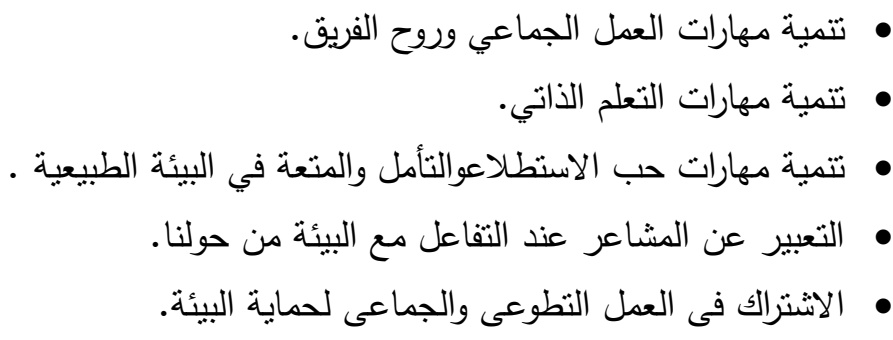

ثالثاً: محتوى البرنامج:

- إجراءوات /ختيار محتويات البرنامج الإثرائيم: نم تحديد محتوى البرنامج الإثرائي في ضوء الأهداف المحددة سلفاً وكذلك في ضوءء:

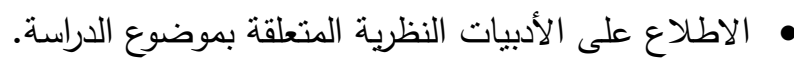

• • الاطلاع على قائمة القضايا والمشكلات البيئية الرئيسة.

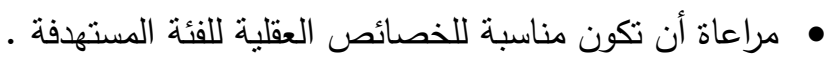

• مراعاة تتظيم محتوي البرنامج بشكل منطقي ومناسب لقرات التلاميذ ومستواهم العقلي.

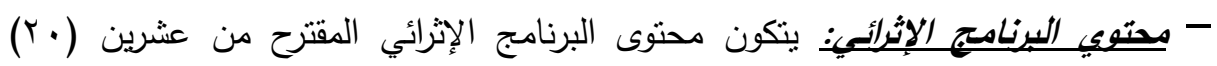

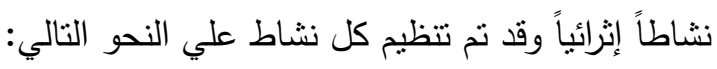

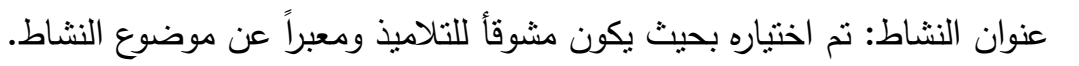

• موضوع النشاط: المفاهيم والقضايا المراد ثتاولها.

• مضدون النشاط : ملخص لما يحتويه النشاط من أهداف ومحتوي وإجراءات.

• مكان تتفيذ النشاط : تم تحديده حسب طبيعة كل نشاط

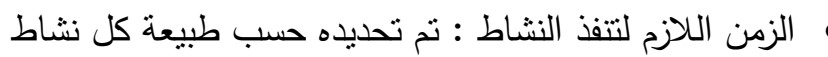

• أهداف النشاط: تم صياغتها بصورة إجرائية حتي يمكن التأكد منها وقياسها.

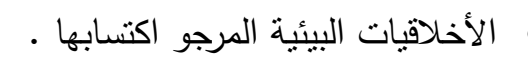

• • مهارات الذكاء البيئي المرجو اكتسابها.

• محتوى النشاط:وهو العناصر الرئيسية لموضوع النشاط . 
• أدوات تتفيذ النشاط: وهي الوسائل والأدوات المستخدمة حسب طبيعة كل نشاط منل جهاز كمبيوتز، شاشة عرض، جهاز عرض projector، صور، لوحات، أقلام، ألوان، بطاقات....إلخ.

• إجراءت تتفيذ النشاط: يسير كل نشاطوفق مراحل استراتيجية التعلم المتمركز حول المشكلة:

لإبعاً: الوسائل والأدوات التعليمية المستخدمة لأنثطة البرنامج: استخدم الباحثون العديد من

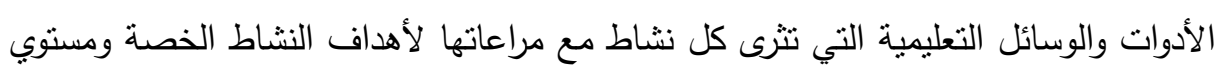

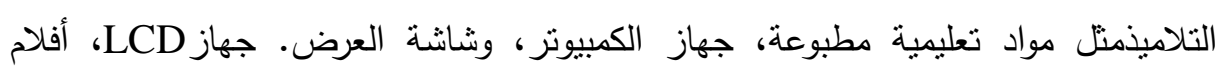

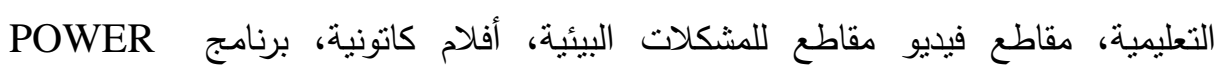

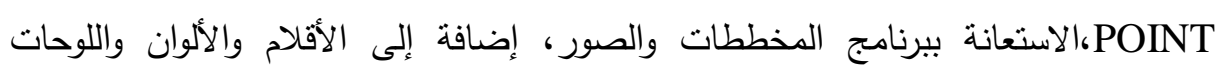
والأوراق.

خامساً: أساليب تنفيذ البرنامج: استخدم في تتفيذ البرنامج مجموعة متتوعة من أساليب التعلم

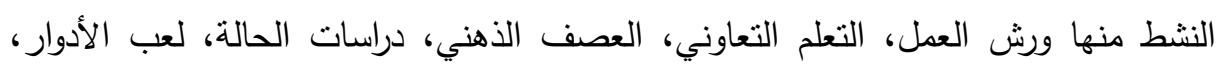
القصة، الثعر ، فجوة المعلومات،بالإضافة إلي المحاضرة، المناقثنة...................

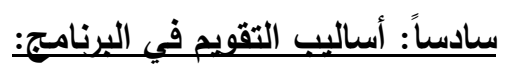
أولاً: الثقوييم القبلي: وتم ذلك من خلال التطبيق القبلي لأداتي القياس وهما مقياس الأخلاقيات البيئية ومقياس الذكاء البيئي للوقوف على مدى تمكن التلاميذ من الأخلاقيات ومهارات الذكاء البيئي يسعى البرنامج إلى تتميتها. ثانياً:التقويم البنائسيْ وتم هذا التقويم أثناء تتفيذ البرنامج ،وتمنل في مجموعة الأسئلة والتدريبات والتطبيقات، والأنشطة المكتوبة وأوراق العمل المصاحبة للمهارات المراد تتميتها

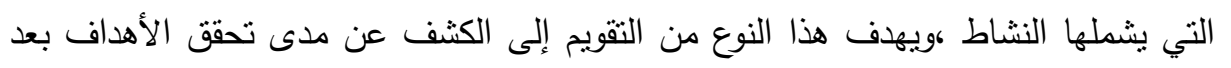
كل فعالية، ودمج التلاميذ في الموقف الصفي وضمان المشاركة الفاعلة.

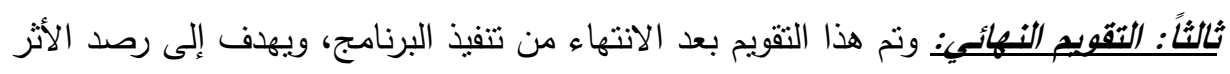

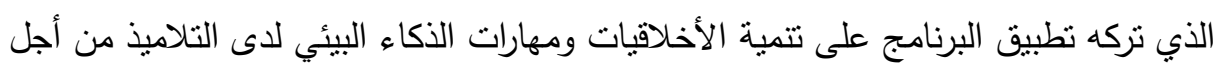

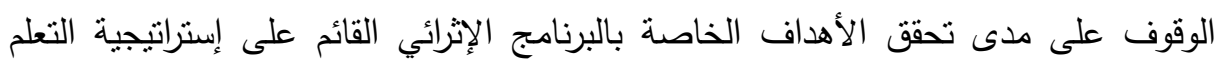

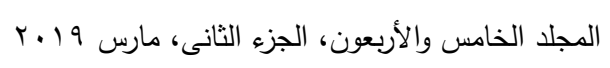


المتمركز حول المشكلة، من خلال التطبيق البعدي لأداتي القياس وهما مقياس الأخلاقيات البيئية ومقياس الذكاء البيئي. سابعاً: ضبط البرنامج: للنأكد من صلاحية البرنامج للتطبيق، عرض الباحثون البرنامج في صورته الأولية على مجموعة من المحكمينفي مجال المناهج وطرق التدريس عامة والتربية البيئية خاصة، وعلم النفس، وذللك بغرض تعرف آرائهم حول مدى ارتباط محتوى البرنامج

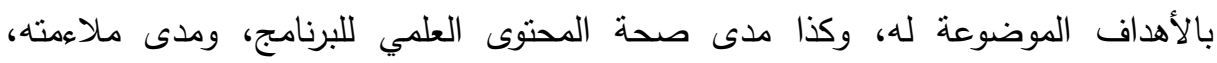
وملاءمة أنشطته للتلاميذ عينة البحث، وقد اتقق السادة المحكمون على ضرورة أن تقتصر ماله المعلومات والمعارف النظرية على المفاهيم الأساسية، والتركيز على تتمية مهارات الذكاء

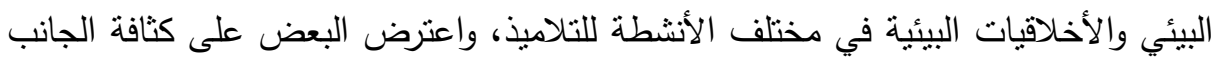

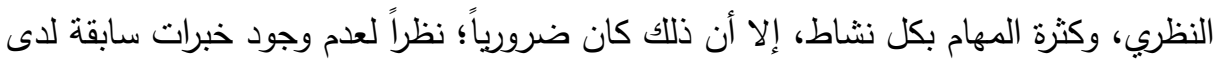
التلاميذ بالقصايا والمشكلات البيئية. ويذلك تكون تمت الإجابة علي السؤال الثالث: ما التصور المقترح للبرنامج الإثرائي القائم علي استراتيجية التعلم المتمركز حول مشكلة لدى تلاميذ المرحلة الاعداديه؟ وللإجابة علي السؤال الرابع: ما فعالية البرنامج الإثرائي علي تتمية بعض الأخلاقيات

$$
\begin{aligned}
& \text { البيئية لدى تلاديذ المرحلة الاعداديه؟ } \\
& \text { تم اتباع الآتي: } \\
& \text { بناء مقياس الأخلاقيات البيئية: }
\end{aligned}
$$

أولاً: هدف المقياس: هدف المقياس إلي التعرف علي مستوي الأخلاقيات البيئية لدي تلاميذ المرحلة الاعدادية.

ثانياً: صياغة مفردات المقياس: قام الباحثون بمراعاة الآتي عند صياغة مواقف المقياس: Е صياغة المقياس في ضوء قائمة الأخلاقيات البيئية والقضايا البيئية الرئيسة .

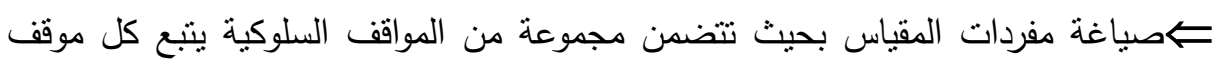
أربعة استجابات تقيس مستوي الأخلاقيات البيئية لدى التلاميذ وهي كالتالي:

$$
\text { • المستوى السطحى (ويعني التمركز حول الإنسان). }
$$

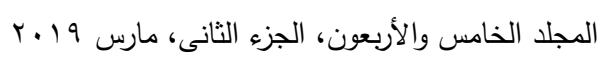




$$
\text { • المستوى المتوسط (ويعني التوسع فى حدود المجنمع ليشمل الجانب البيئي). }
$$
• المستوى العميق (ويعني التمركز حول الجانب الايكولوجي للبيئة و نقدير البيئة وإحترامها لئية بإعتبارها ذات قيمة في حد ذاتها وليس تقديرها من خلال علاقتها بالإنسان ومصالحة).

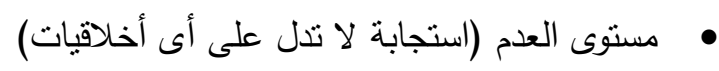

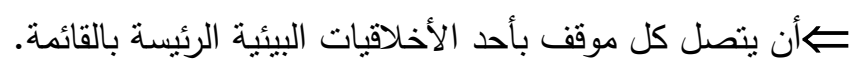
Ł Ґ

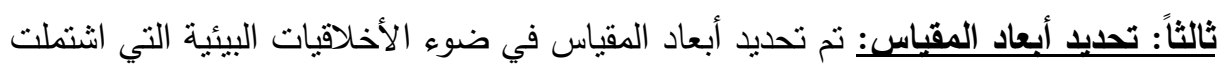
عليها قائمة القضايا البيئية. رلايعاً: الصورة المبئية للمقياس: الثنملت على ( • ع ) موقفاً. خامساً: صدق المقياس: للتأكد من صدق وسلامة المقياس علمياً تم اتباع الآتي:تم عرضه

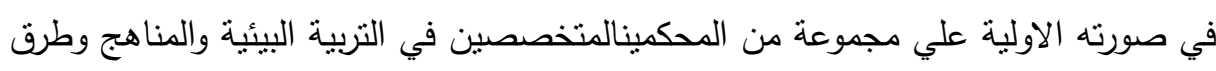
التنريس وذللك لاستطلاع آرائهم في هذه المقياس من حيث مدي سلامة العبارات وملائمنها

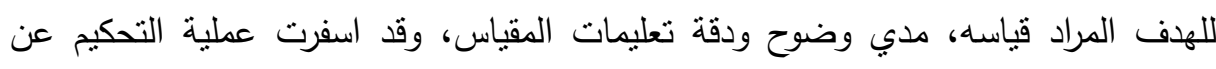

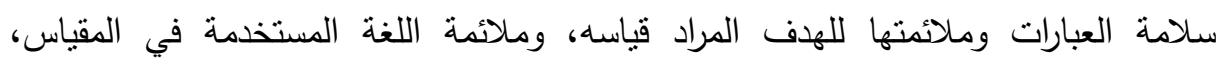
وملائمة العبارات لمستوي التلاميذ وإلي إعادة صباغة وتعديل بعض عبارئه ولهارات المقياس، إلغاء

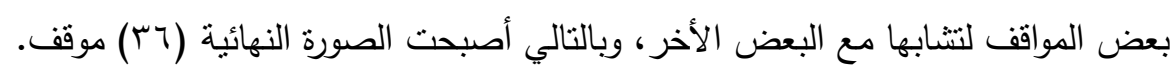
سادساً: ثبات المقباس: ويقصد به مدي انساق نتائج المقياس.وقد استخدم الباحثون طريقة

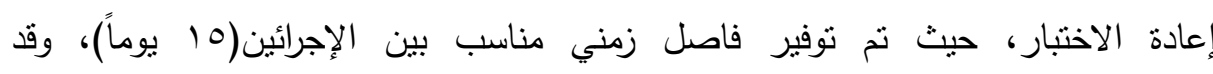

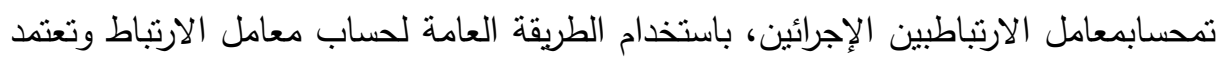

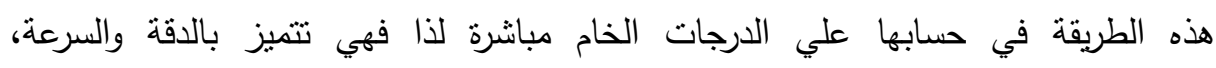
وبالتعويض كانت قيمة معامل الارتباط(9, • )، مما يدل علي ثبات المقياس.

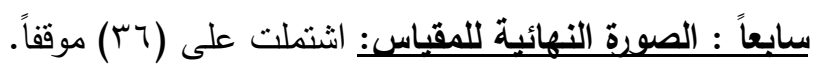


جدول (1) (1) مواصفات مقياس الأخلاقيات البيئية

\begin{tabular}{|c|c|c|c|c|}
\hline الارجة & المفردات & أرقام المفردات & القضية البيئية & م \\
\hline 11 & 7 & 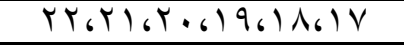 & اختلال التوازن البيئي & 1 \\
\hline 10 & 0 & $\left.0, \Sigma_{6} Y_{6} Y_{6}\right)$ & مشكلات المياه & r \\
\hline 11 & 7 & $r 961 \cdot 6961_{6} V_{6} 7$ & النتوع البيولوجى & r \\
\hline 11 & 7 & $1761061 \leqslant 61 \sigma_{6} 1 Y_{6} 11$ & ت تغير المناخ & $\varepsilon$ \\
\hline 10 & 0 & TY, & الاستهلاك المفرط & 0 \\
\hline ir & $\varepsilon$ & Tr & مشكلات الطاقة & 7 \\
\hline ir & $\varepsilon$ & YA , TV GYT GYE & المخلفات الصلبة & $\mathrm{V}$ \\
\hline المجموع & $1 \cdot 1$ & T & المجموع & \\
\hline
\end{tabular}

ثامناً: تعليمات المقياس: راع الباحثون تحديد هدف المقياس، حث التلاميذ علي إبداء آرائهر بحرية دون قيد.

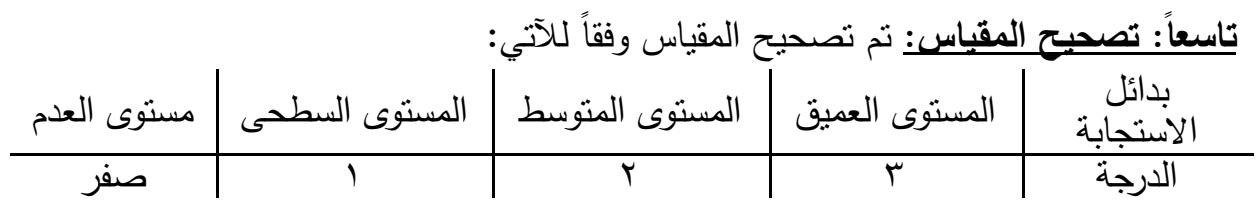
وللإجابة علي السؤال الخامس: ما فعالية البرنامج الإثرائي علي تتمية مستوي الذكاء البيئي لدى تلاميذ المرحلة الاعداديه؟ تم اتباع الأتي: بناء مقياس الأكاء البيئي:

أولاً: هدف المقياس: التعرف عليمستوي الذكاء البيئي لدي التلاميذ المرحلة الاعدادية. ثانياً: صياغة عبارات المقياس: تم صياغة المقياس في ضوء قائمة مهارات الذكاء البيئي،

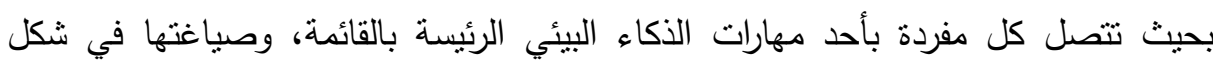
مواقف وأسئلة تثير ذكاء التلاميذ البيئي.

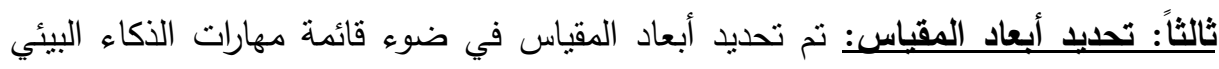
والقضايا البيئية.

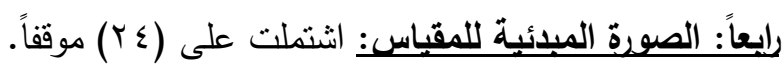

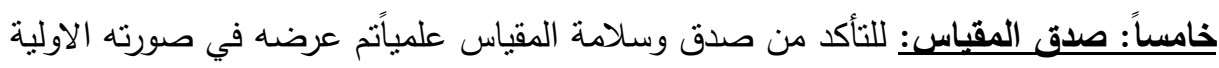
علي مجموعة من المحكمين وذللك لاسنطلاع آرائهم في مدي سلامة العبارات وملائمتها

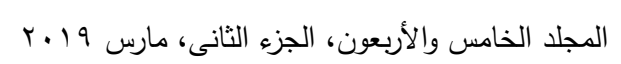


للهدف المراد قياسه، ومدي ملائمة اللغة المستخدمة، ومدي وضوح ودقة تعليمات المقياس، وقد اسفرت عملية التحكيم عن سلامة العبارات وملأئمتها للاهف المراد قياسه، ملائمة اللغة وفئة

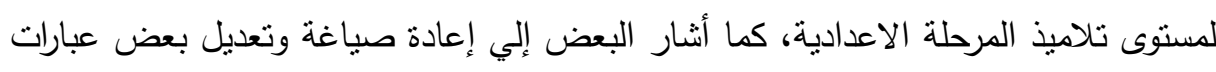

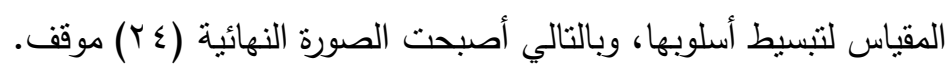
سادساً: ثبات المقياس: اعتمد الباحثون على أسلوب إعادة التطبيق للتأكد من ثبات المقياس،

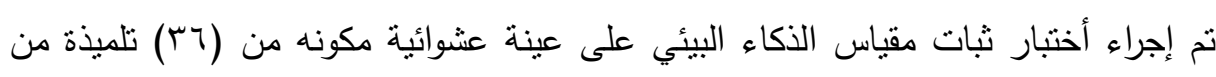

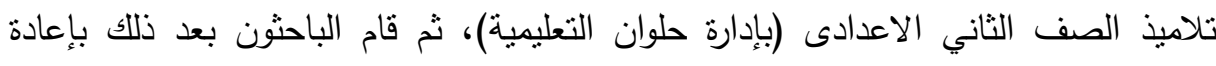

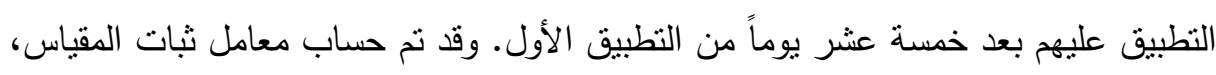

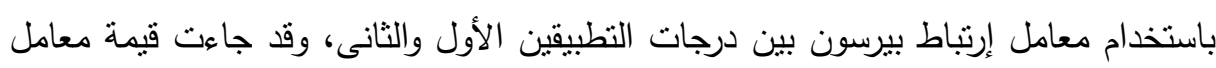
الارتباط(19, • )، مما يدل علي ثبات المقياس مما يعطى مؤشراً لإمكانية التطبيق الميدانى.

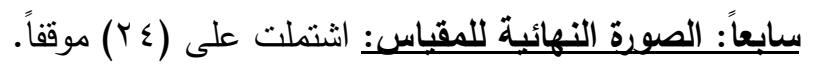

\begin{tabular}{|c|c|c|c|c|}
\hline \multicolumn{5}{|c|}{ جدول (T): مواصفات معياس الدكاء البيئي } \\
\hline الارجة & عدد المفردات & 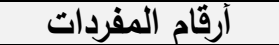 & القضية البيئية & 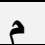 \\
\hline 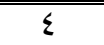 & $\varepsilon$ & $1 \leqslant 61 \%$ ، 967 & اختلال التوازن البيئي & 1 \\
\hline r & r & $1 \cdot$ ، 1 & ل مشكلات المياه & r \\
\hline 0 & 0 & YY & التتوع البيولوجي & $r$ \\
\hline$\varepsilon$ & $\varepsilon$ & Yr 6 IV، $\left.6 \varepsilon_{6}\right) T$ & ت تغير المناخ & $\varepsilon$ \\
\hline$\varepsilon$ & $\xi$ & Y)6r.619610 & الاستهلاك المفرط & 0 \\
\hline 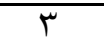 & 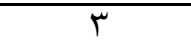 & $r \varepsilon$ ، $1 \wedge 6 V$ & مشكلات الطاقة & 7 \\
\hline$r$ & $r$ & 1160 & المخلفات الصلبة & V \\
\hline TE & $T \varepsilon$ & & 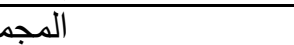 & \\
\hline
\end{tabular}

ثامناً: تعليمات المقياس: راع الباحثون تحديد هدف المقياس، حث التلاميذ علي التقكير

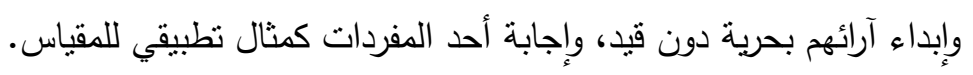

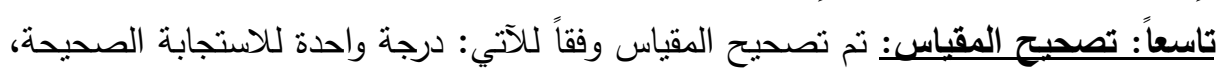

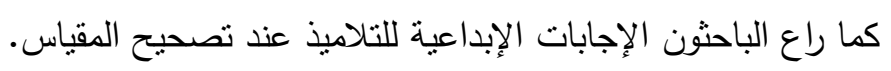

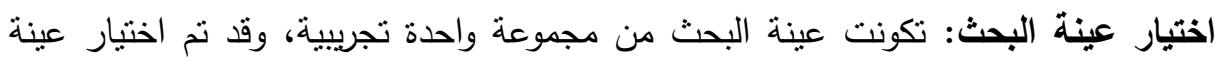
البحث من تلميذات مدرسة الثيماء الاعدادية للبنات بإدارة التبين التعليمية، محافظة حلوان. 


\begin{tabular}{|c|c|c|c|c|}
\hline المجموعة التجريبية & الأدوات البحث التلميذات & الفصل & التلإديداتة في & المدرسة \\
\hline$\varepsilon$. & $\varepsilon \varepsilon$ & $\varepsilon / r$ & إدارة التبينين & الاعدادية اللثبنات \\
\hline
\end{tabular}

وقد نم تحديد تلاميذ عينة البحث (المجموعة التجريبية)، وقد اشتملت المجموعة التجريبية

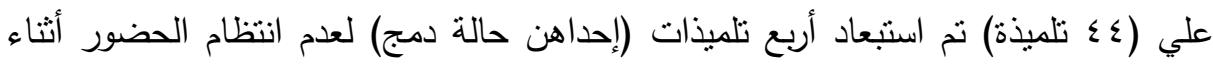
تجريب تطبيق البرنامج الاثرائي والتطبيق البعدي لأدوات البحث، ليصبح عداد البعات تلاميذ المجموعة التجريبية ( • ـ تلميذة). إجراء التطبيق القبلي لأداتي البحث: قام الباحثون بتطبيق أداتي البحث (مقياس الذكاء البيئي

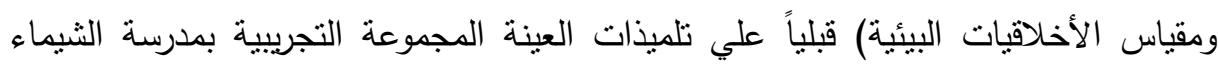
الاعدادية للبنات، وقد استغرق التطبيق (ع حصص دراسية) على يومين في الأسبوع الثاني

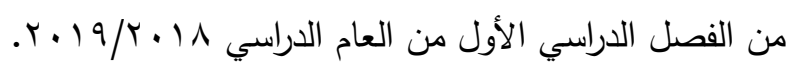
تطبيق البرنامج الاثرائي على التلميذات عينة البحث: قام الباحثون بتطبيق البرنامج الاثرائي

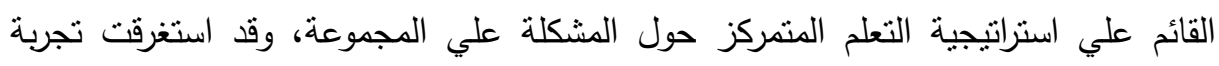

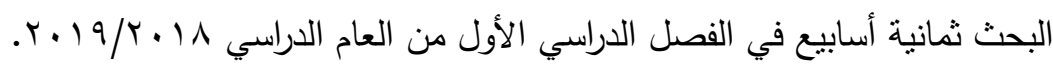

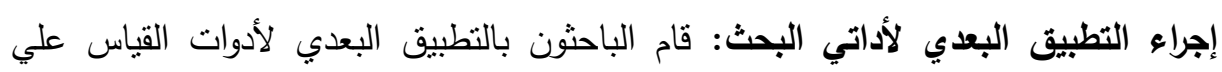

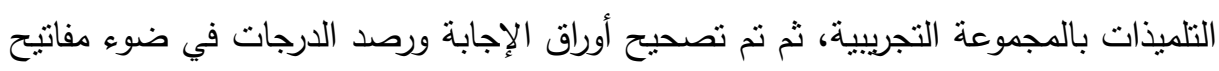
التصحيح الخاصة بكل أداة.

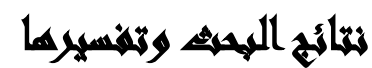

معالجة النتائج في ضوء فروض البحث باستخدام الأساليب والمعادلات الإحصائية تمت فيهات معالجة نتائج الدراسة للتحقق من صحة الفروض كما يلي: الفرض الأول: يوجد فرق دال إحصائياً بين متوسطي درجات تلاميذ المجموعة التجريبية في درجات مقياس الأخلاقيات البيئية قبل تطبيق البرنامج الإثرائي وبعده لصالح التطبيق البعدي.

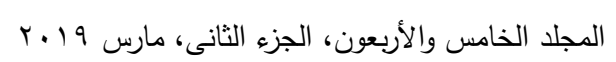


لاختبار صحة هذا الفرض تم حساب متوسط درجات تلاميذ المجموعة التجريبية في

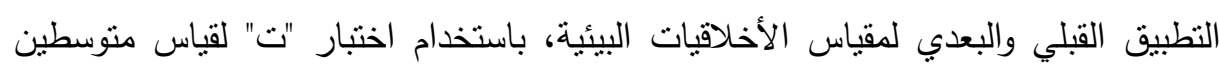
مرتبطين.

جدول (ع): نتائج التطبيقين القبلى والبعدى لمقياس الأخلاقيات البيئية (المجموعة التجريبية)

\begin{tabular}{|c|c|c|c|c|c|c|c|c|c|}
\hline \multirow[b]{2}{*}{ الأثر } & \multirow[b]{2}{*}{ مريع } & \multirow{2}{*}{ قديمة } & \multirow[b]{2}{*}{ الحرية } & \multicolumn{2}{|c|}{ 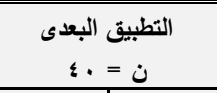 } & \multicolumn{2}{|c|}{ التطبيق القبلى } & \multirow{2}{*}{ النهائية لكل } & \multirow{2}{*}{ المقياس } \\
\hline & & & & الانحراف & المتوسط & الانحراف & المتوسط & & \\
\hline - VYY & . OrY & $9, r Y)$ & rq & $r, 900$ & $9,0 \ldots$ & 1,191 & $r, \leqslant V_{0}$ & 11 & التنازل البيأن \\
\hline rגו, & - 97V & $\varepsilon \vee, \vee \vee q$ & rq & אז人, & Ir,q & , & $\varepsilon, \vee \vee \vee$ & 10 & مشكلة \\
\hline$\cdot, q . \varepsilon$ & $\cdot, \wedge \backslash \wedge$ & $|\Lambda, v| r$ & rq & $r, V T_{1}$ & $11, \cdot r_{0}$ &., 017 & $\curlyvee, \wedge \ldots$ & 11 & البيولوجى التتوع \\
\hline - AYO & $\cdot, 7 \lambda)$ & $1 r, 910$ & rq & r,rqA & $9, .0$. & $\cdot, \wedge \leqslant \uparrow$ & $\varepsilon, .0$. & 11 & تغنير \\
\hline • & $\cdot$, V & $1 r, \wedge 0$ & rq & $r, . q$. & $৭, \wedge \vee 0$ & $\cdot, 000$ & $r, \ldots$ & 10 & الاستهلاك \\
\hline r, q14 & & $|9, \lambda r|$ & rq & $1,9 \leqslant 1$ & 9, YYO & $\cdot, v \cdot V$ & r,vo. & r & مشكلة \\
\hline •, qVर & $\cdot, 9 \leqslant V$ & $r v, r \infty 0$ & $r q$ & $1,0$. & $9,9 \vee 0$ & •, \&Ar & $r, 10$. & r & الصللفة \\
\hline r, & • & $19, \lambda \cdot 9$ & rq & $1 \leqslant, V \leqslant 0$ & סזותו & $r, v) \leq$ & $r \varepsilon, \ldots$ & 1.1 & الكلية \\
\hline
\end{tabular}

$$
\text { ويتضح من جدول (؛ ) ما يلي: }
$$

- وجود فرق دال إحصائياً بين التطبيق القبلى والنطبيق البعدى في الأخلاقيات البيئية

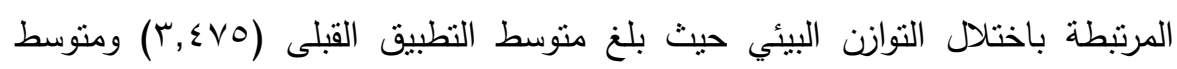

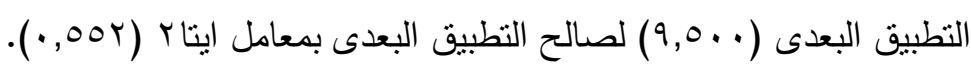
- وجود فرق دال إحصائياً بين التطبيق القبلى والتطبيق البعدى في الأخلاقيات البيائية

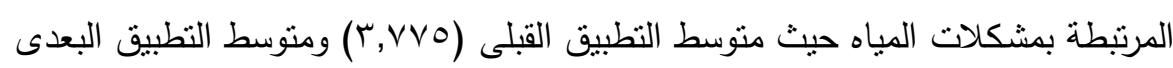

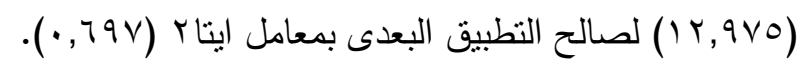

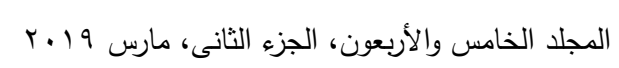


- وجود فرق دال إحصائياً بين النطبيق القبلى والتطبيق البعدى في الأخلاقيات البيئية

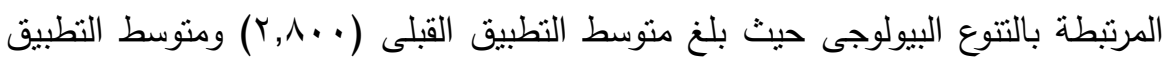

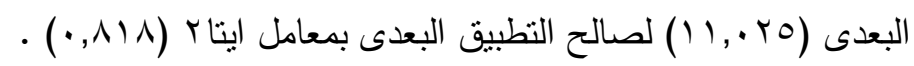
- وجود فرق دال إحصائياً بين التطبيق القبلى والتطبيق البعدى في الأخلاقيات البيئية المرتبطة بتغير المناخ حيث بلغ متوسط التطبيق القبلى (.0...ع) ومنوسط التطبيق

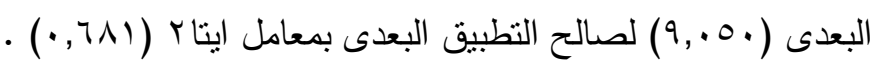
- وجود فرق دال إحصائياً بين النطبيق القبلى والتطبيق البعدى في الأخلاقيات البيئية المرتبطة بالاستهلاك المفرط حيث بلغ متوسط التطبيق القبلى ( . . بـ) ومتوسط التطبيق

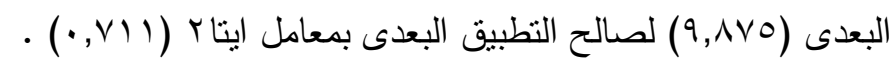
- وجود فرق دال إحصائياً بين التطبيق القبلى والتطبيق البعدى في الأخلاقيات البيئية

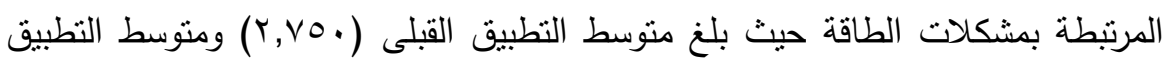

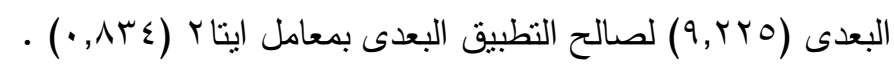
- وجود فرق دال إحصائياً بين التطبيق القبلى والتطبيق البعدى في الأخلاقيات البيئية

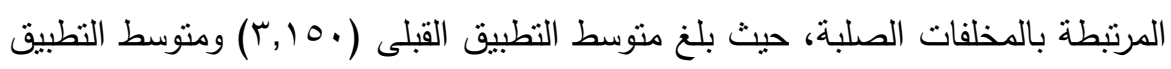

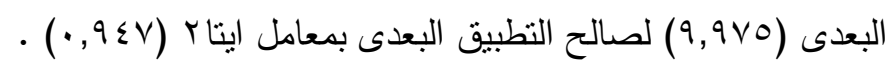

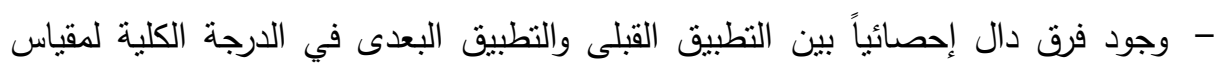

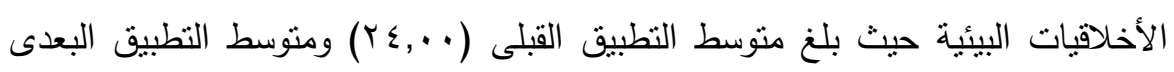

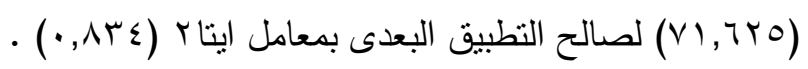

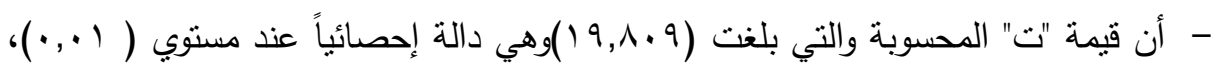

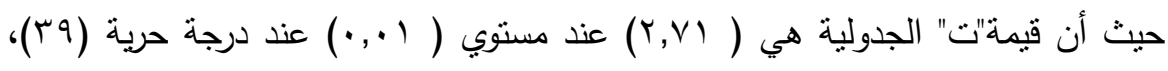
ويتضح من هذا أنه أكبر من قيمة "ت" الجدولية؛ مما يدل علي وجود فرق دال إحصائياً بين متوسطي درجات المجموعة التجريبية فى التطبيق القبلوالبعدي لمقياس الأخلاقيات البيئية لصالح النطبيق البعدي. - ومن ثم يثبت صحة الفرض الثاني من هذه الدراسة. 


\section{نتائج التطبيقين القبلى و البعدى لمقياس الأخلاقيات البيئية}

$$
71.625
$$
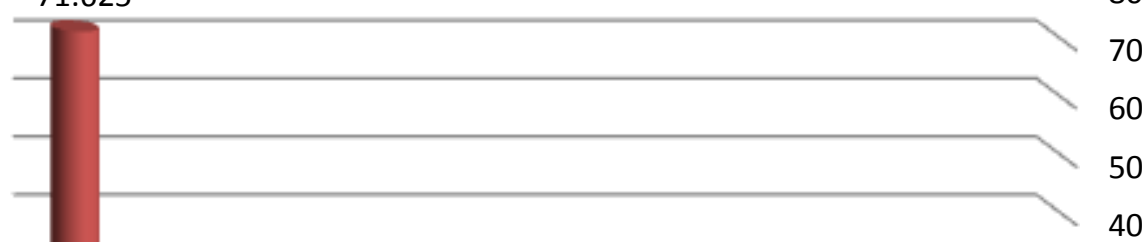

24

$\begin{array}{lllllll}9.975 & 9.225 & 9.875 & 9.05 & 11.025 & 12.975 & 9.5\end{array} 2$

\begin{tabular}{|l|l|l|l|l|l|l|l}
3.15 & 2.75 & 3 & 4.05 & 2.8 & 4.775 & 3.475 & 10
\end{tabular}

اختلال مشكلات التنوع تغير الاستهلاك مشكلات المخلفات الارجة

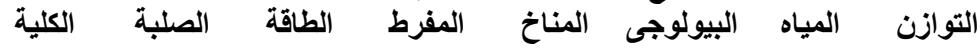

بعدى ص قبلي

شكل (Y): نتائج النطبيقين القبلى والبعدى لمقياس الأخلاقيات البيئية

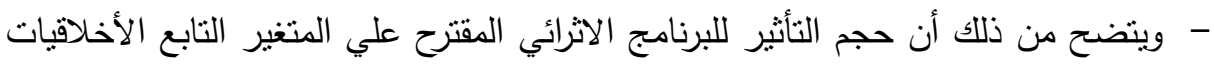
البيئية (ץ/9, •) والتي استهدفها البحث أكبر من (^, •) وهي النسبة المحددة لإعطاءمؤشر عال من حجم التأثير ، إذن مقدار حجم التأثير كبير . 
جدول (•): حساب نسبة الكسب المعدل لبلاك لمقياس الأخلاقيات البيئية

\begin{tabular}{|c|c|c|c|c|c|c|}
\hline \multirow{2}{*}{ الكستوى } & \multirow[b]{2}{*}{ الكسبة } & \multicolumn{2}{|c|}{ متوسطي الارجة للتطبيقين } & \multirow{2}{*}{ 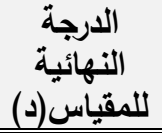 } & \multirow[b]{2}{*}{ محاور المقياس } & \multirow[b]{2}{*}{ b } \\
\hline & & (ضعدي) & القبلي & & & \\
\hline جيد & $1, \varepsilon$ & $9,0 \ldots$ & $r, \varepsilon \vee 0$ & 11 & اختلال التوازن & 1 \\
\hline مقبول & $1, r$ & $1 \mathrm{r}, 9 \vee 0$ & $\varepsilon, \vee \vee 0$ & 10 & مشكلات المياه & r \\
\hline مقبول & $1, r$ & $11, \cdot Y_{0}$ & $r, \wedge \ldots$ & 11 & التتوع البيولوجى & $r$ \\
\hline جيد & $1, \varepsilon$ & $9, .0$. & $\varepsilon, .0$. & 11 & تغير المناخ & $\varepsilon$ \\
\hline جيد & $1, \varepsilon$ & $q, \wedge \vee 0$ & $r, \ldots$ & 10 & الاستهلالك المفرط & 0 \\
\hline مقبول & $1, r$ & $9, r$ Yro & r,Vo. & Ir & مشكلات الطاقة & 7 \\
\hline 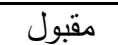 & $1, r$ & $9,9 \vee 0$ & $r, 10$. & $\pi$ & المخلفات الصلبة & $\mathrm{V}$ \\
\hline مقبول & 1,7 & $V 1,7 Y 0$ & $r \varepsilon, \cdot$ & $1 \cdot 1$ & المجموع الكلى & \\
\hline
\end{tabular}

يوضح جدول (0):

- وجود فرق دال إحصائياً بين التطبيق القبلي والتطبيق البعدى في مقياس الاخلاقيات البيئة

$$
\text { وقد سجلت نسبة الكسب لبلاك نسب مقبولة وجيدة. }
$$

- وقد بلغت قيمة الكسب المعدل (T, ()، إذن نسبة الكسب المعدل مقبولة لأنها أكبر من وندة

$$
\text { الواحد الصحيح. }
$$

الفرض الثاني: يوجد فرق دال إحصائياً بين متوسطي درجات تلاميذ المجموعة التجريبيةفي مقياس الذكاء البيئي قبل تطبيق البرنامج الإثرائي وبعده لصالح التطبيق البعدي.

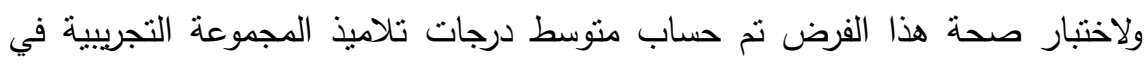
التطبيق القبلي والبعدي لمقياس الذكاء البيئي، وتم استخدام اختبار "ت" لمتوسطين مرتبطين . 
جلول (†): نتائج النطبيقين القبلى والبعدى لمقياس الذكاء البيئي ( المجموعة التجريبية )

\begin{tabular}{|c|c|c|c|c|c|c|c|c|c|}
\hline \multirow{2}{*}{ الأثجر } & \multirow[b]{2}{*}{ مريع } & \multirow{2}{*}{ قالة } & \multirow{2}{*}{ الحرية } & \multicolumn{2}{|c|}{ التطبيق البعدى = . } & \multicolumn{2}{|c|}{ ن التطبيق القبلى . ؛ } & \multirow{2}{*}{ محل النهائية } & \multirow[b]{2}{*}{ المقياس } \\
\hline & & & & الانحراف & المتوسط & الانحراف & المتوسط & & \\
\hline$\cdot, \vee \wedge \varepsilon$ & • & $11,1 \leq 9$ & rq & $\cdot, V \cdot V$ & r, ro. & צדי, • & $\cdot, \wedge 0$. & $\varepsilon$ & التنازن \\
\hline$\cdot, 9 \cdot 1$ & r & $1 \wedge, r q \leq$ & rq & $\cdot, \varepsilon .0$ & $1, \wedge .$. & $\cdot, r \wedge 0$ & - IVo & r & مشكلات \\
\hline 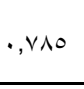 & • & $11,1 v_{0}$ & rq & $1, \cdot 11$ & $\curlyvee, \wedge .$. & •, EYV & $\cdot, 10$ & 。 & 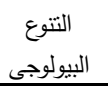 \\
\hline$\cdot, 9.7$ & $\cdot, \lambda r$. & $1 \Lambda, \Lambda \tau \varepsilon$ & rq & $\cdot, 0 . \varepsilon$ & r,oo. & $\cdot, 101$ & $\cdot, 9 \vee 0$ & $\varepsilon$ & تغنير \\
\hline$\cdot, 9 \leq \varepsilon$ & - А९Y & ro,rדV & rq & •, r.14 & r,9०. & $\cdot, 0.1$ & .,OVo & $\varepsilon$ & الاستهلالك \\
\hline$\cdot, 91 \leqslant$ & •, Aro & 19,107 & $r q$ & $\cdot, 0.1$ & r,OVo & -,$\leqslant q$. & • rvo & $r$ & مشكلات \\
\hline$\cdot, \wedge \cdot \vee$ & r, ror & $|r, \cdot \Lambda|$ & rq & צוצז, & 1,10 & $\cdot, 0 \leqslant 0$ & $\cdot, 7$. & r & الصلفة الصلفات \\
\hline$\cdot, 9 \leq \varepsilon$ & $\cdot, \wedge 91$ & $r_{0}, 1 \wedge V$ & $r q$ & $r, T 00$ & 17, VYo & $1,7) \varepsilon$ & $\varepsilon, \varepsilon \ldots$ & $r \varepsilon$ & الكلية \\
\hline
\end{tabular}

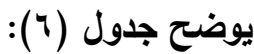

- وجود فرق دال إحصائياً بين التطبيق القبلى والتطبيق البعدى في الذكاء البيئي المرتبط

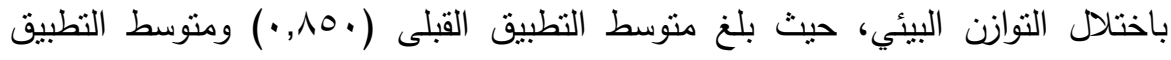

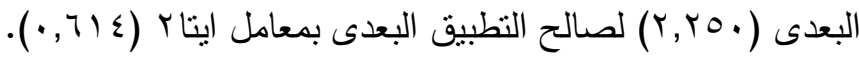

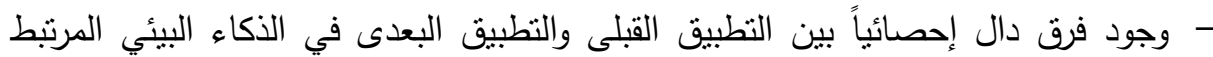

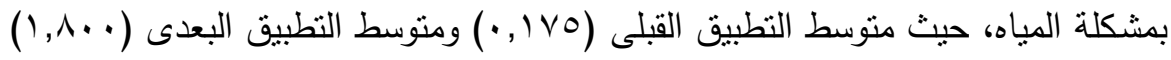
لصالح التطبيق البعدى بمعامل ايتاب (س الم, •). 
- وجود فرق دال إحصائياً بين التطبيق القبلى والتطبيق البعدى في الذكاء البيئي المرتبط

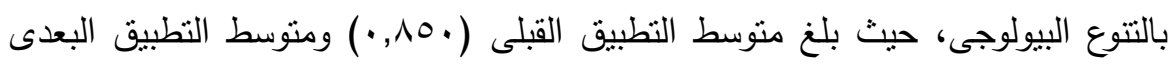

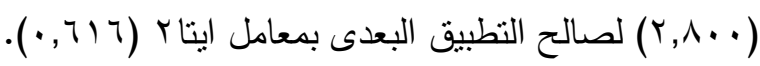
- وجود فرق دال إحصائياً بين النطبيق القبلى والنطبيق البعدى في الذكاء البيئي المرتبط

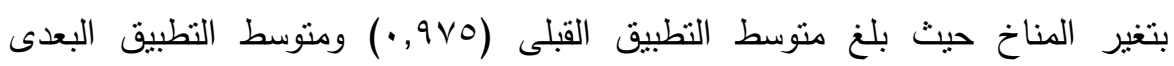

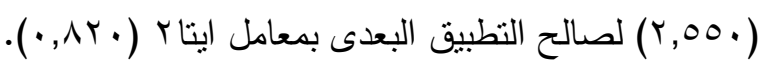
- وجود فرق دال إحصائياً بين التطبيق القبلى والتطبيق البعدى في الذكاء البيئي المرنبط

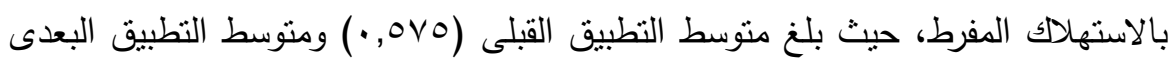

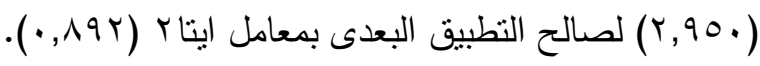
- وجود فرق دال إحصائياً بين النطبيق القبلى والتطبيق البعدى في الذكاء البيئي المرتبط

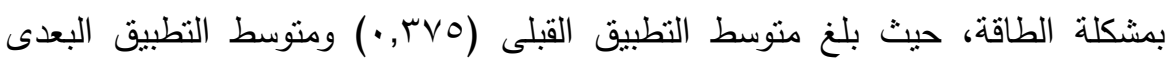

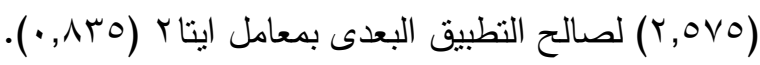
- وجود فرق دال إحصائياً بين النطبيق القبلى والتطبيق البعدى في الذكاء البيئي المرنبط

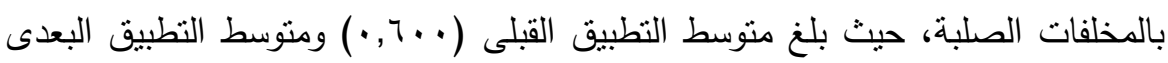

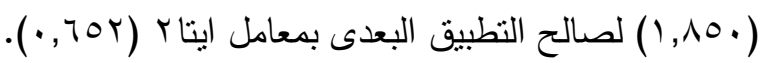

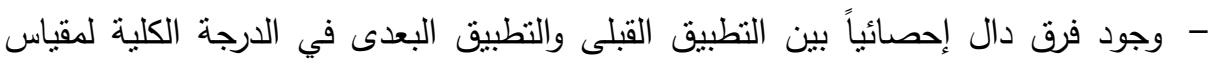

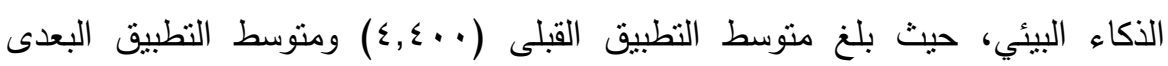

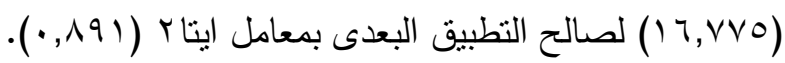

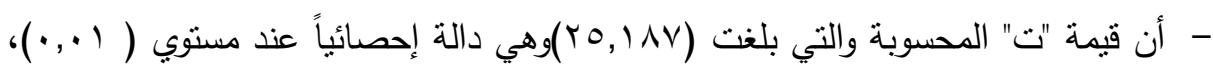

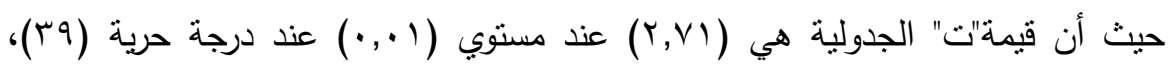
ويتضح من هذا أنه أكبر من قيمة " ت " الجدولية؛ مما يدل علي وجود فرق دال إحصائياً بين منوسطي درجات المجموعة التجريبية فى التطبيق القبلى والبعدي لمقياس الذكاء البيئي لصالح التطبيق البعدي، ومن ثم يثبت صحة الفرض الثاني من هذه الدراسة. 
- ويتضح من الجدول السابقأن حجم التأثير للبرنامج الاثرائي المقترح علي المتغير التابع

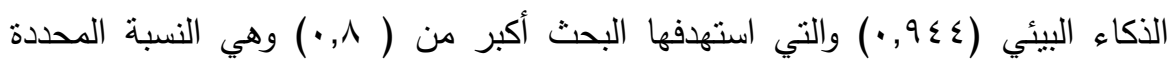
لإعطاء مؤثر عال من حجم التأثثر .

\section{نتائج التطبيقين القبلى و البعدى لمقياس الأكاء البيئي}

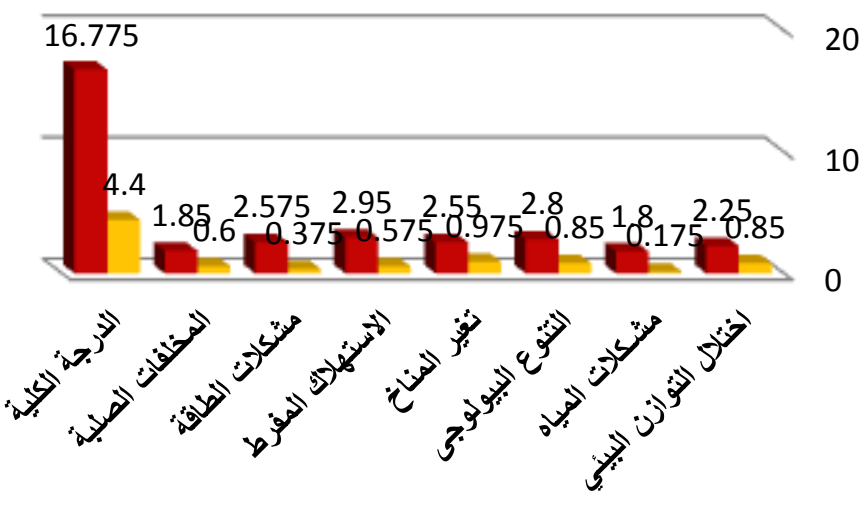

بعدى ه قبلي

شكل (r): نتائج التطبيقين القبلى والبعدى لمقياس الذكاء البيئي

جدول (V): حساب نسبة الكسب المعدل لبلاك لمقياس الذكاء البيئي

\begin{tabular}{|c|c|c|c|c|c|c|}
\hline \multirow{2}{*}{ الكستوى } & \multirow{2}{*}{ نسبة } & \multicolumn{2}{|c|}{ متوسطي الارجة } & \multirow{2}{*}{ 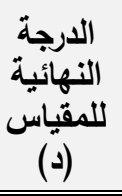 } & \multirow{2}{*}{ أداة التطبيق } & \multirow{2}{*}{ r } \\
\hline & & البعدي & القبلى & & & \\
\hline مقبول & 1,1 & r, ro. & $\cdot, \wedge 0$. & $\varepsilon$ & اختلال التوازن & 1 \\
\hline مقبول & $1, r$ & $1, \wedge \ldots$ & $\cdot, 1 \vee 0$ & $r$ & مشكلات المياه & $r$ \\
\hline مقبول & $1, r$ & $r, \wedge \ldots$ & $\cdot, \wedge \circ$. & 0 & التتوع البيولوجى & $r$ \\
\hline مقبول & $1, r$ & $r, 00$. & $\cdot, 9 \vee 0$ & $\varepsilon$ & تغير المناخ & $\varepsilon$ \\
\hline مقبول & $1, r$ & $r, 90$. &., $0 \vee 0$ & $\varepsilon$ & الاستهلاك المفرط & 0 \\
\hline جيد & 1,7 & r,OVO & - rVo & $r$ & مشكلات الطاقة & 7 \\
\hline مقبول & $1, r$ & $1,10$. & $\cdot, 7 \ldots$ & $r$ & المخلفات الصلبة & V \\
\hline جيد & $1, \varepsilon$ & $17,8 \vee 0$ & $\varepsilon, \varepsilon \ldots$ & $Y \leq$ & المجموع الكلى & \\
\hline
\end{tabular}


يوضح جدول (V):

- وجود فرق دال إحصائياً بين النطبيق القبلي والتطبيق البعدى في مقياس الذكاء البيئي وقد سجلت نسبة الكسب لبلاك نسب مقبولة وجيدة. - وقد بلغت قيمة الكسب المعدل (ع, ()، إذن نسبة الكسب المعدل مقبولة لأنها أكبر من بن الواحد الصحيح.

\section{تمخسير المنتائم}

أثبت التطبيق الميداني ما يلي:

- وجود فرق دال إحصائياً بين منوسطي درجات المجموعة التجريبية فى التطبيق القبلوالبعدي لمقياس الأخلاقيات البيئية لصالح التطبيق البعدى؛ حيث بلغئي درجات متوسط درجات

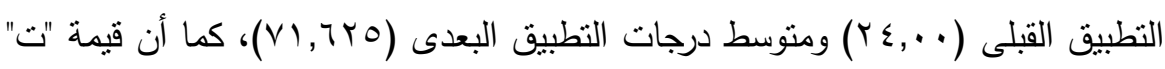

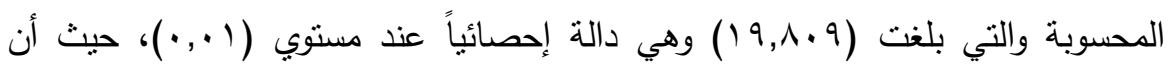

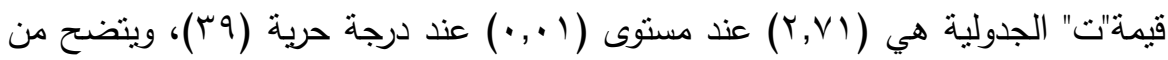

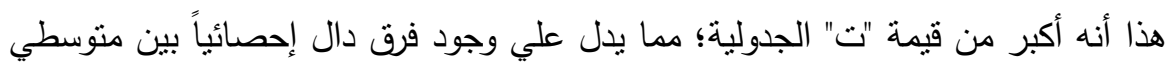
درجات المجموعة التجريبية فى التطبيق القبلى والبعدي لمقياس الأخلاقيات البيئية لصالح التطبيق البعدي.

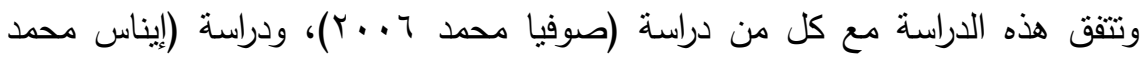

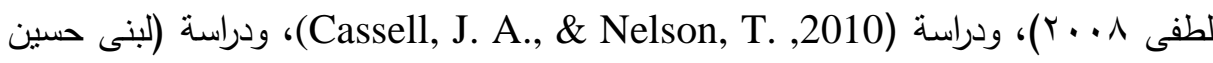

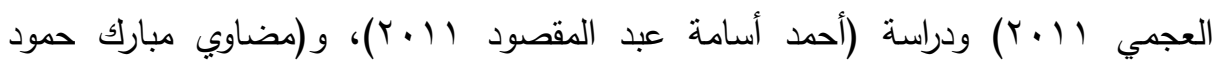

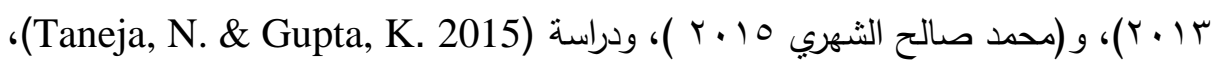
ودراسة (Kele \& Özer N. 2016)، ودراسة ودرية (KARAKAYA, F., \& YILMAZ) (Nikhat, ودراسة (Cassell, J. A., \& 2017) ودراسة) (Melson, T. 2010) (Perrin, J. L. 2017) ودراسة (Khan, Z. 2017)

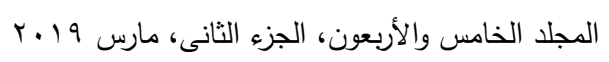


- وجود فرق دال إحصائياً بين منوسطي درجات المجموعة التجريبية فى التطبيق القبلى والبعدي لمقياس الذكاء البيئي لصالح التطبيق البعدي؛ حيث بلغ منوسط درجات درجات التطبيق

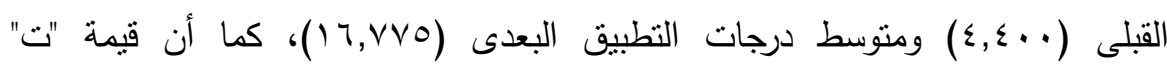

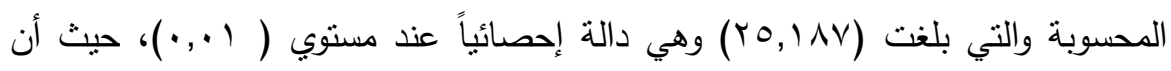

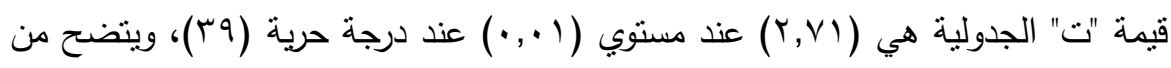
هذا أنه أكبر من قيمة " ت " الجدولية؛ مما بدل علي وجود فرق دال إحصائياً بين منوسطي درجات المجموعة التجريبية فى التطبيق القبلى والبعدي للقياس الذكاء البيئي

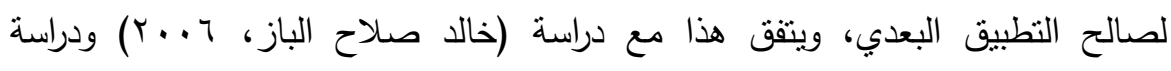

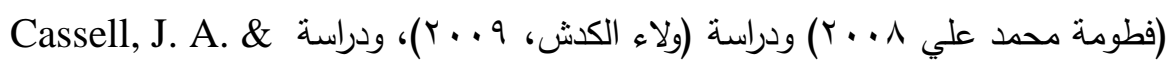

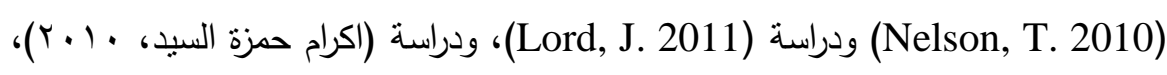
Meyers, E. M., \& Tirri, K. \& Nokelainen, P. 2012)، ودراسة ودراسة (Liاسة) (Bittner, R. 2012, February)

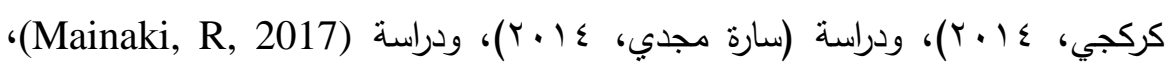

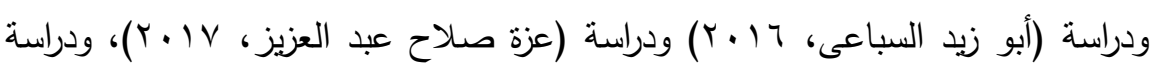

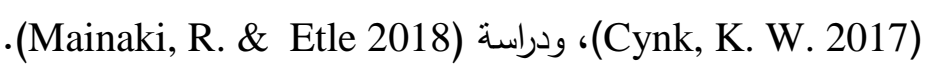

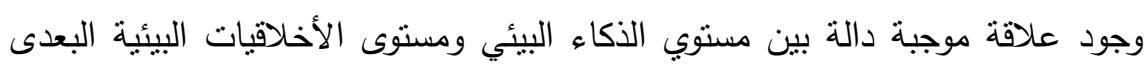

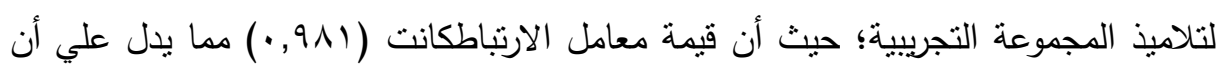
العلاقة بين الذكاء البيئي والأخلاقيات البيئية علاقة موجبة وقوية، وذات دلالة معنوية بلغت الاتبه 1., , • وهى قيمة اقل من 0 •, •، وهذا يتفق مع دراسة (Tirri, K. \& Nokelainen 2012) - فعالية البرنامج الاثرائي أكبر من الواحد الصحيح (كما تقاس بنسبة الكسب المعدل لبلاكد)

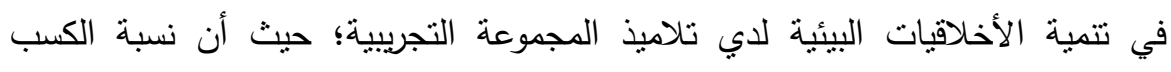

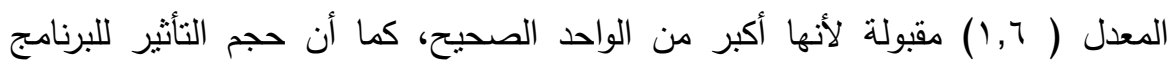

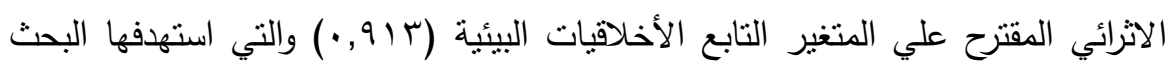

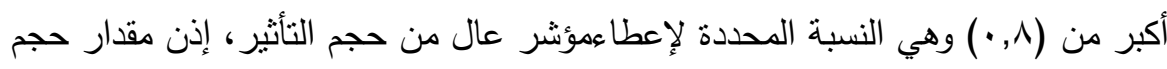
- التأثنير كبير من 
- فعالية البرنامج الاثرائي أكبر من الواحد الصحيح (كما تقاس بنسبة الكسب المعدل لبلاك) في تتمية الذكاء البيئيلدي تلاميذ المجموعة التجريبية؛ حيث أن نسبة الكسب المبن المعدل (1, ( ) مقبولة لأنها أكبر من الواحد الصحيح، كما أن حجم التأثنر للبرنامج الاثرائي

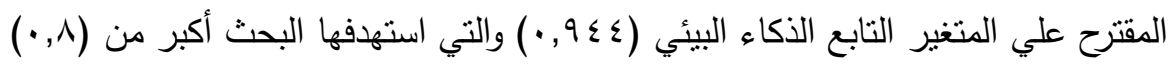
وهي النسبة المحددة لإعطاعمؤشر عال من حجم التأثنر . - لعل أبرز العوامل التي ساهمت في نتمية الأخلاقيات البيئية والذكاء البيئيلدى التلميذات

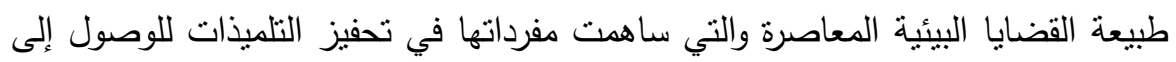
مستوى منقدم من التفكير الفعال في نلك القضايا وفهمها بشكل عميق، وذلك من خلاد استخدام البرنامج الإثرائي القائم علي استراتيجية التعلم المتمركز حول مشكلة وبالتالي أصبحت التلميذات قادرات على تقديم أفكاراً أكثر تفصيلاً مما ساهم في تتمية الأخلاقيات الإتراتئ البيئية والذكاء البيئي لاديهن.

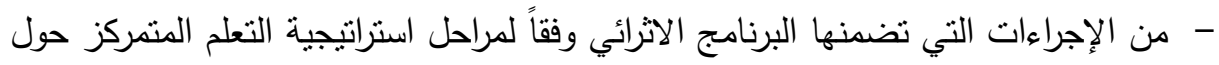

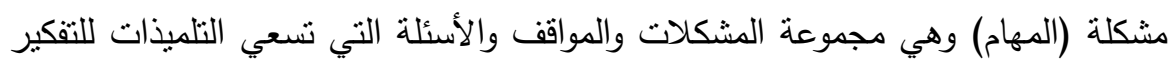
بها لحلها، والتي اتسمت بالتدرج والتسلسل المنطقي للموضوعات والقضايا التي يستهدفها كل نشاط، كما حفزت الاستثارة العقلية للتلميذات في مناخ يشجع علي الحوار والمناقثة ولثة بطريقة ممتعة ومشوقة تساعدهم على اتخاذ القرارات المناسبة والمتعدة الإجابات والحلول عناخ

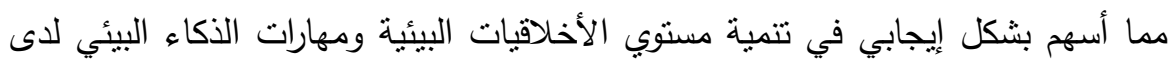

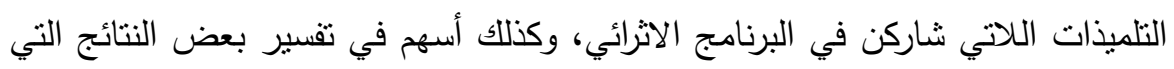
توصلت إليها هذه الدراسة.

- ومن الإجراءات التي تضمنها البرنامج الاثرائي أيضاً وفقاً لمراحل استراتيجية التعلم

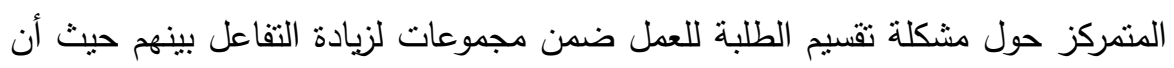

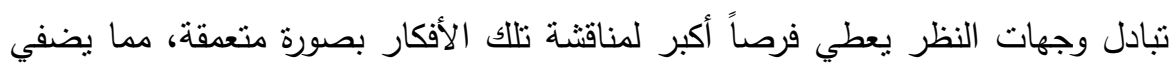

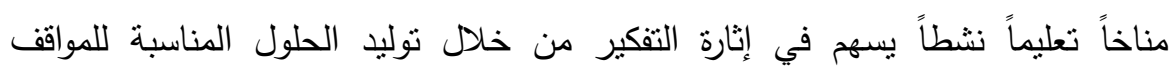

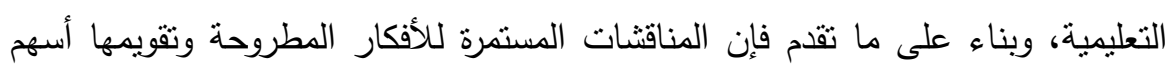

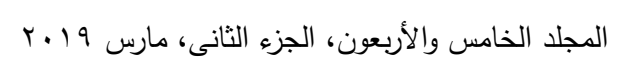


بشكل إيجابي في تتمية مستوي الأخلاقيات البيئية ومهارات الذكاء البيئي لدى التلميذات اللاتي شاركن في البرنامج الاثرائي، وكذلك أسهم في تفسير بعض النتائج التي توصلت

$$
\text { إليها هذه الدراسة. }
$$

- توظيف مستحدثات التعلم الاكتروني وتقنياته المختلفة في انشطة البرنامج كان له أثر لـان كبير في فعالية البرنامج الإثرائي ويتفق هذا مع كل من دراسة (مضاوي مبارك حمود

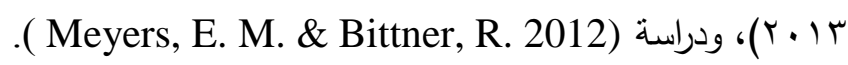

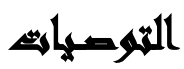

فى ضوء ما توصل إليه البحث من نتائج يمكن تقديم التوصيات التالية:-

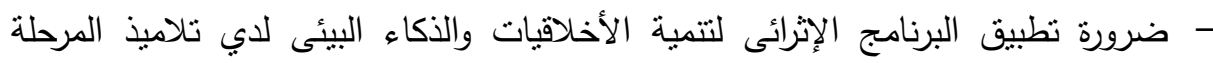
الإعدادية.

- ضرورة الاهتمام بموضوعات الأخلاقيات والذكاء البيئي في المناهج الدراسية المختلفة.

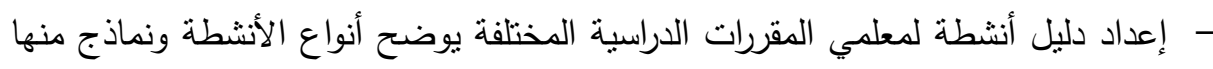
قائمة علي التتوع والاختلاف وطرق تتفيذها وإجراءاتها الخاصة والأدوات والوسائل التعليمية

$$
\text { المطلوبة. }
$$

- - ضرورة تضمين مهارات الذكاء البيئي والأخلاقيات بالمناهج الدراسية المختلفة.

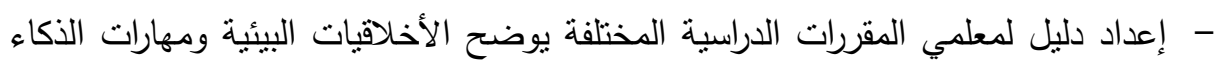
التي يمكن تتميتها لدي التلاميذ بكل صف دراسي.

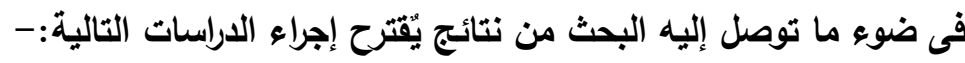

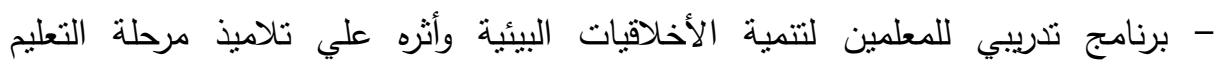
الأساسي. - فعالية برنامج اثرائي لتتمية الأخلاقيات والذكاء البيئي للتناميذ في المراحل الدراسية المختلفة (الإبندائية والثانوية). - فعالية برنامج قائم علي المسرح ولعب الأدوار في تتمية مهارتي الإدراك والحساسية البيئية لاي تلاميذ مرحلة التعليم الأساسي.

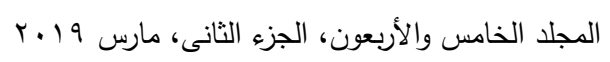


- دراسة تقويمية للمناهج الدراسية بمرحلة النعليم الأساسي في ضوء مهارات الذكاء البيئي.

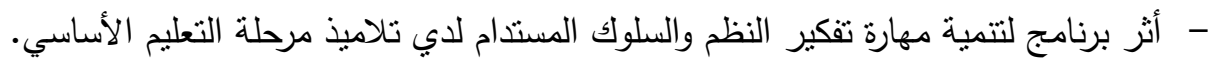

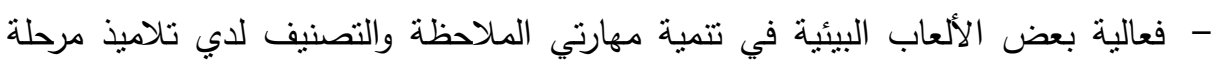

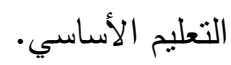
- أثر برنامج إثرائي لتتمية مهارات التفكير البيئي للتلاميذ بمرحلة التعليم الأساسي.

\section{المرابr}

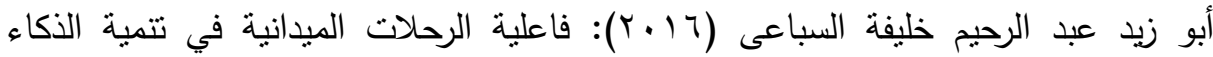

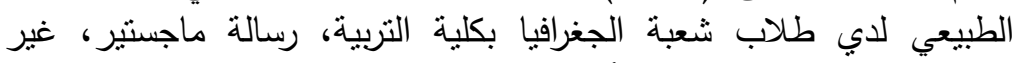

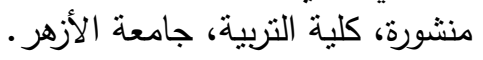

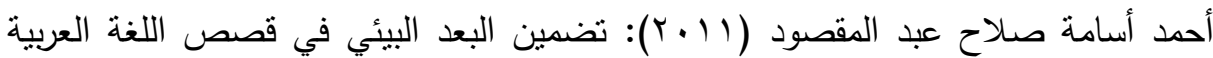

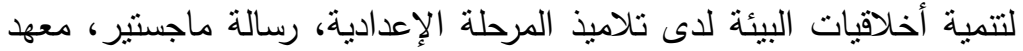

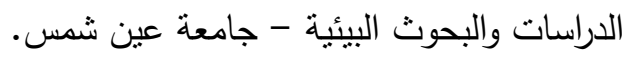

أحمد اللقاني، علي الجمل (1999 (1): معجم المصطلحات التربوية المعرفة في المناهج وطرق

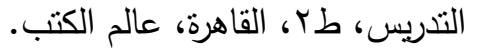

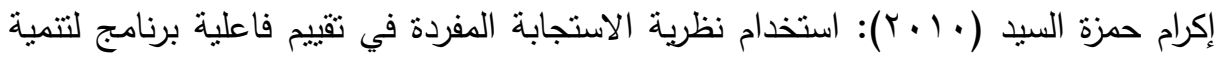

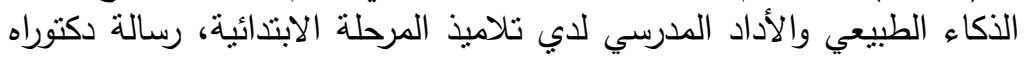

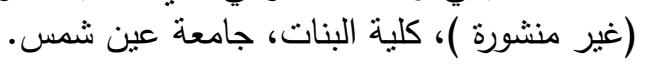

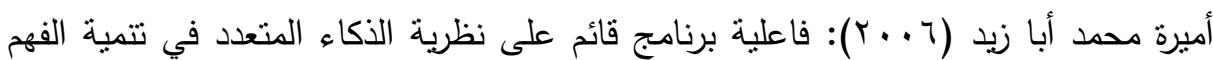

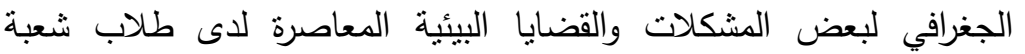

الجغرافيا بكلية التربية،رسالة ماجسنتير ، كلية التربية، جامعة الإسكندرية. لإنيات

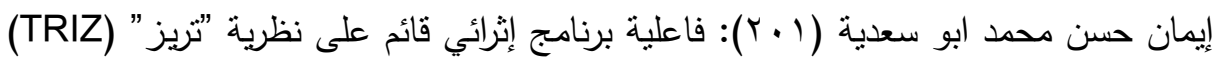

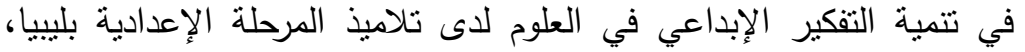

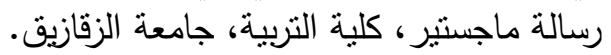

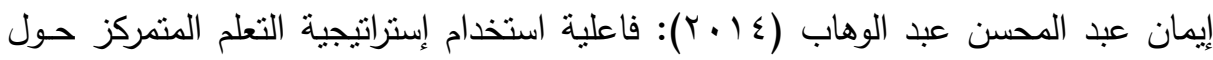

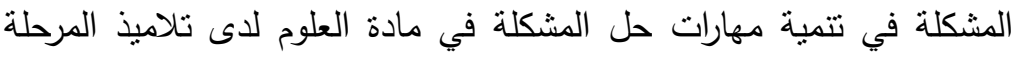

$$
\text { الإعدادية، رسالة ماجستير ، كلية التربية، جامعة بنها. }
$$




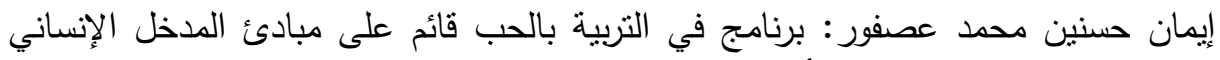

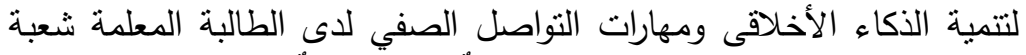

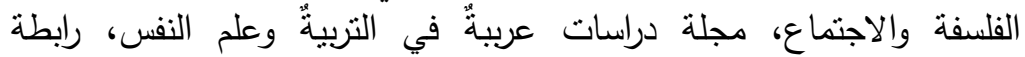

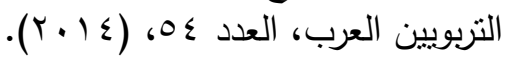

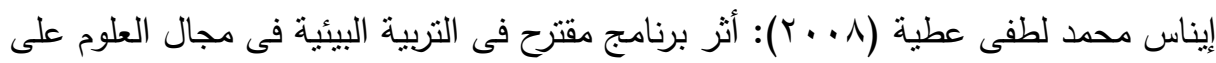
تتمية بعض المفاهيم والأخلاقيات البيئية لدى طلاب كلاب كليات التربية، رسالة ماجستير ، كلية التربية، جامعة الزقازيق.

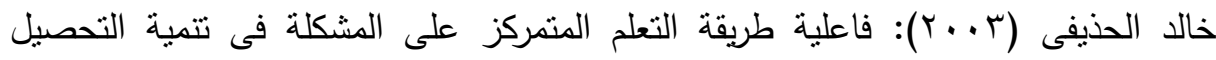

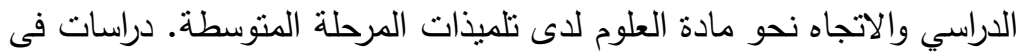

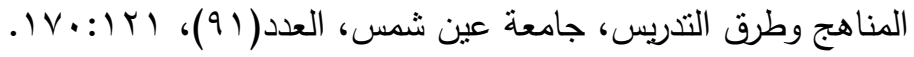

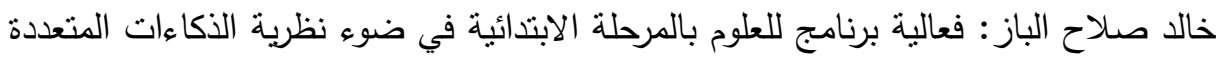

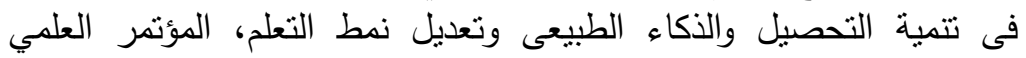

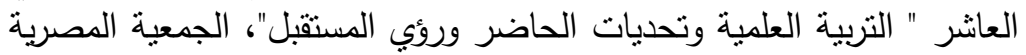

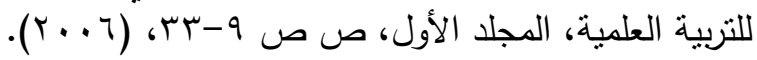
خالد عبداله الحموري: أثر برنامج إثرائي في التربية البيئية في تتمية مهارات التفكير الابتكاري

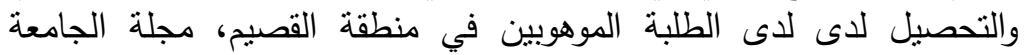

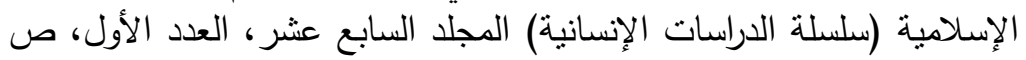

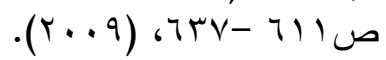

ريهام رفعت محمد: فاعلية استخدام استراتيجية التعلم المتمركز حول المشكلة فى تدريس وحدة

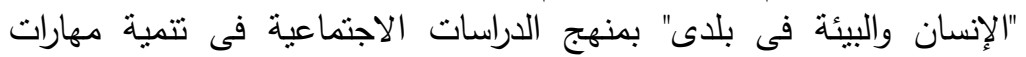

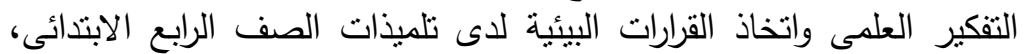

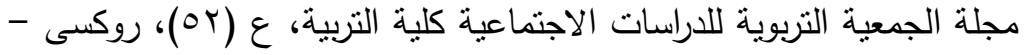

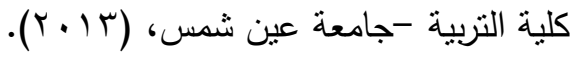

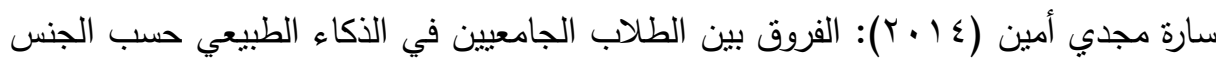

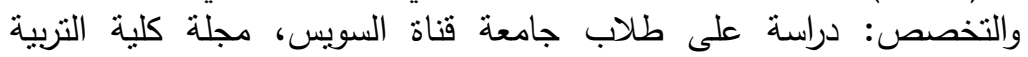

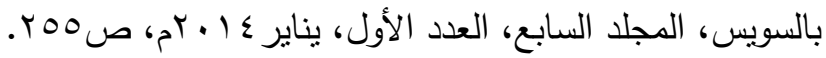

سميحة محمد سليمان (ع ( ب): فعالية استخدام استراتيجيتي التعلم المتمركز حول المشكلة

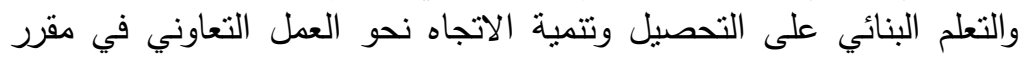
العلوم لدى طالبات الصف الثاني المتوسط بمحافظة الطائف، المجلة التربية التربية،

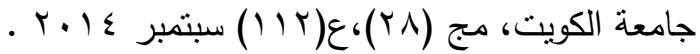




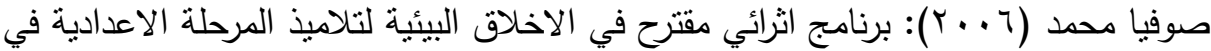

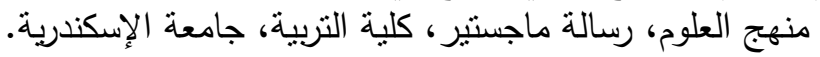

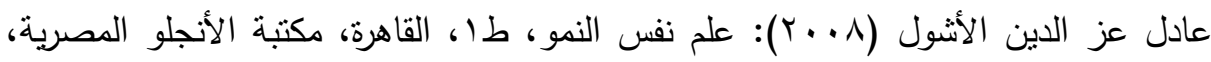
ص ص ص الان

عبداله محمود، يوسف سيد، ثناء هاثم: الاتجاهات الفلسفية حول علاقة الإنسان بالبيئة:

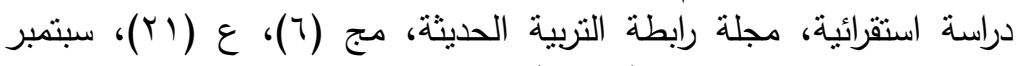

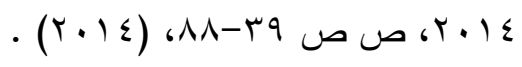

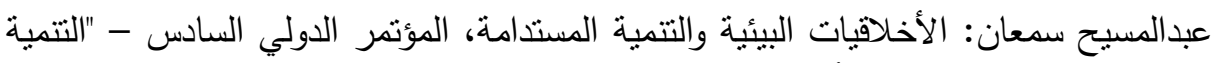

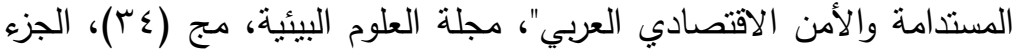

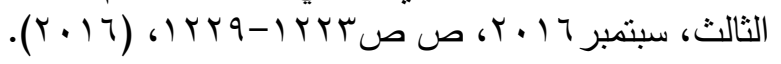

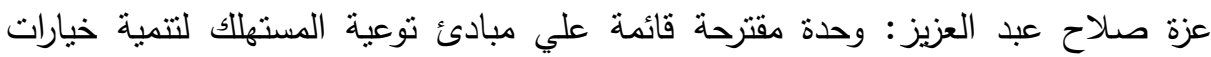
الاستهلالك المستدام والمسئولية الاجتماعية فى التربية الأسرية لدى تلاميذ

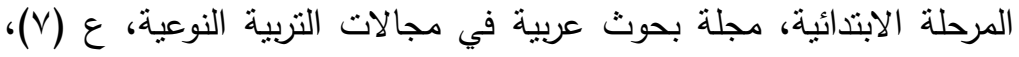

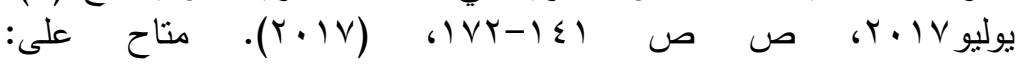
http://search.mandumah.com/Record/827430

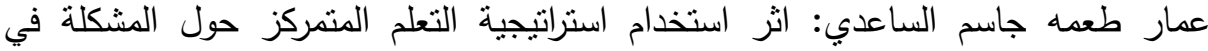

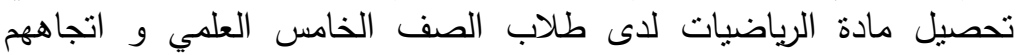

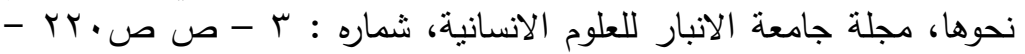

$$
\cdot(r \cdot 11) \text { (r) }
$$

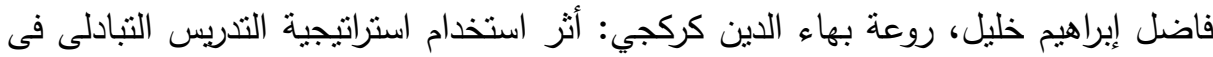

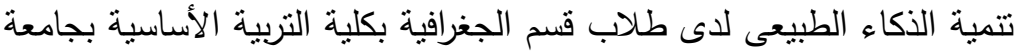

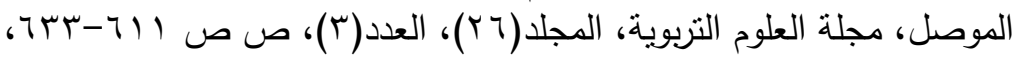

$$
\cdot(r \cdot 1 \leq)
$$

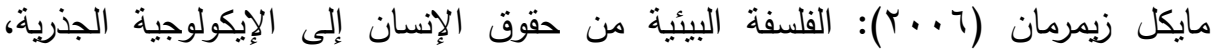

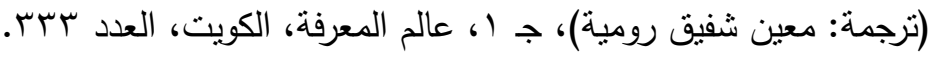

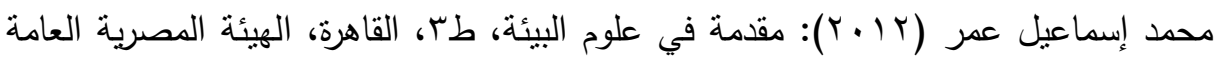
للكتاب، صع (بـ (ب) : 


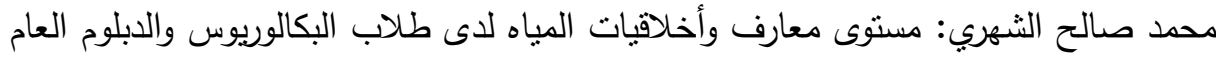

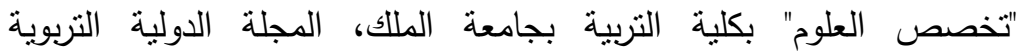

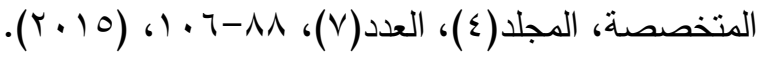

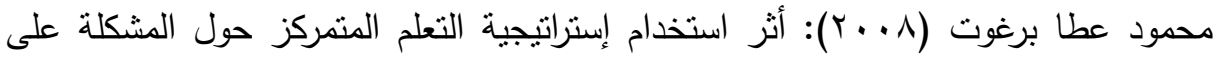

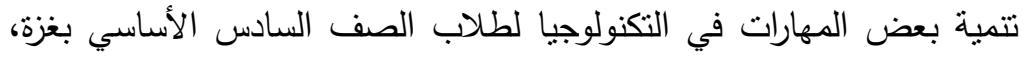

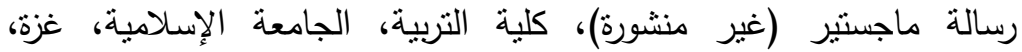

$$
\text { فلسطين. }
$$

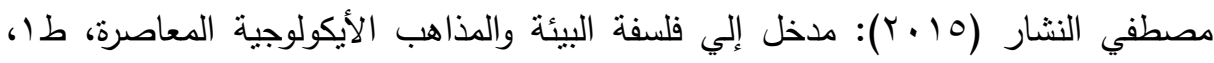

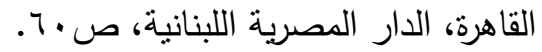

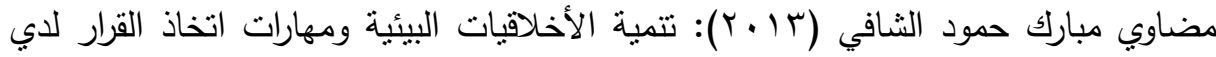

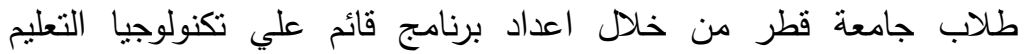

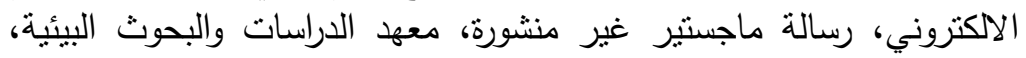

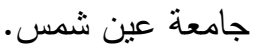

نادر عبد اله العدل (ع . . ب): الوعى الدينى وعلاقته بالأخلاق البيئية لدى طلاب التعليم الثانوى، رسالة ماجستير (غير منشورة)، كلية التربية، جامعة المنصورة. لألانية

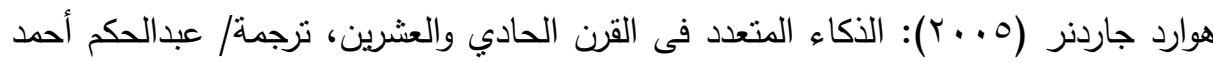
الخزامي، دار الفجر للنشر والتنوزيع.

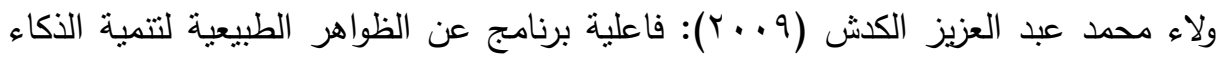
الطبيعي لطفل الروضة، رسالة ماجسنير غير منشورة، كلية رياض الاض الأطفال،

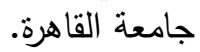

يسري طه محمد: أثر استخدام إستراتيجية التعلم المتمركز حول المشكلة في تتمية التحصيل

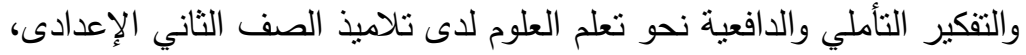

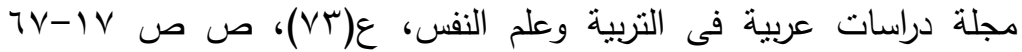
$\cdot(r, 17)$

Cassell, J. A. \& Nelson, T. (2010): Visions lost and dreams forgotten: Environmental education, systems thinking, and possible futures in American public schools.Teacher Education Quarterly, 37(4), 179-197. 
Cynk, K. W. (2017): Level of environmental intelligence among university students from selected countries of Central and Eastern Europe. Civil Engineering and Environmental Systems, 1-23.

Gola, B. (2017): Is formal environmental education friendly to nature? Environmental ethics in science textbooks for primary school pupils in Poland. Ethics and Education, 1-17.

G. S. Nayal, Sarita Bhatt: Development And Standardization Of Ecological Intelligence Scale. Indian Streams Research Journal, Vol.(4), Issue.(5)V, June-2014, Doi: 10.9780/22307850, (2014). Available online at: http://isrj.org/UploadedData/4813.pdf

Kaur, M.; Kang, T. K. \& Sharma, S.: Environmental ethics among adolescents: A study of gender and locale difference. Advance Research Journal of Social Science, 7(2),(2016).

Kele \& Özer, N.: Determination of Pre-Service Science Teachers' Level of Awareness of Environmental Ethics in Relation to Different Variables. International Journal of Environmental and Science Education, 11(14), 7286-7296, (2016).

Lord, J. (2011): The Contribution of Environmental Studies Curricula to Environmental Decision Making (Doctoral dissertation, Walden University).

Mainaki, R.: Value Of Ecological Intelligence In Lettuce In District Parongpong District Bandung Barat. Jurnal Geografi Gea, 17(2), 124-134, (2017)..

Mainaki, R.; Kastolani, W. \& Setiawan, I. (2018): Ecological Intelligence Level Of Hight School Students In Cimahi City. In SHS Web of Conferences (Vol. 42, p. 00062). EDP Sciences.https://doi.org/10.1051/shsconf/20184200062

$$
\text { المجلد الخامس والأربعون، الجزء الثانى، مارس } 9 \text {. ب ج }
$$


Meyers, E. M. \& Bittner, R. (2012): Green washing the digital playground: how virtual worlds support ecological intelligence... or do they?. In Proceedings of the rFebruary 2012 iConference (pp. 608-610). ACM.

Nikhat, Khan, Z.: Construction and Validation of Environmental Ethics Attitude Scale. IRA International Journal of Education and Multidisciplinary Studies (ISSN 2455-2526), 7(3), 240249.doi: http://dx.doi.org/10.21013/jems.v7.n3.p9, (2017).

Perrin, J. L. (2017): Recognizing connection to nature: Perspectives from the field. Applied Environmental Education \& Communication, 1-11.

Taneja, N., \& Gupta, K. (2015): Environmental Ethics and Education-A Necessity to Inculcate Environment Oriented Cognizance. Environmental Ethics, 2(1).

Tirri, K. \& Nokelainen, P. (2012): Measuring multiple intelligences and moral sensitivities in education (Vol. 5). Springer Science \& Business Media.

Wheatly, G. H: Constructivist Perspective on Science Mathematics Learning, Journal of Science Education, Vol 75, No. 1, (1991). 
مجلة العلوم البيئية

معهد الدراسات والبحوث البيئة - جامعة عين شمس لئس

\title{
THE EFFECTIVENESS OF AN ENRICHMENT \\ PROGRAM BASED ON PROBLEM CENTERED \\ LEARNING STRATEGY ON DEVELOPING \\ ENVIRONMENTAL ETHICS AND INTELLIGENCE
}

AMONG PREPARATORY STAGE PUPILS

\author{
Safya A. M. Ali ${ }^{(1)}$; Abdel Messeh S. Abdel Messeh ${ }^{(1)}$ \\ Reham R. Mohamed ${ }^{(1)}$ and Mai E. Khalifa ${ }^{(2)}$ \\ 1) Institute of Environmental Studies \& Research, Ain Shams \\ University 2) Faculty of Education, Helwan University
}

\begin{abstract}
ABSTACT
The research aims to develop environmental ethics and intelligence among Preparatory Stages Pupils through designing an Enrichment Program Based On Problem Centered Learning Strategy and measuring its effectiveness. a list of environmental ethics and intelligence skills should be developed to pupils in preparatory stage pupils and designing the enrichment program included (20 an enriching activity.. Environmental Ethics scale was designed which included (36 items), and Environmental intelligence scale which included (24 items).The research Tools was applied pre application of the program on the experimental group. The program was applied on an experimental group (40 pupil), then the research Tools was applied post application.

The results pointed out, there was a statistically significant difference among the middle-grades pupils in the experimental group in environmental ethics scalebefore the applying of treatment and beyond for the post application. There was a statistically significant difference among the middle-grades pupils in the experimental group scores measure student performance in environmental intelligence before applying the treatment and beyond for the post application.
\end{abstract}

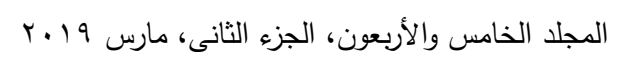


The research recommended the necessity of applying the enrichment Program to develop environmental ethics and Intelligence among preparatory stage pupils and involving environmental ethics and intelligence skills on various curricula.

Key words: environmental ethics- Environmental intelligence Problem Centered Learning Strategy - Enrichment Program.y 